\title{
Comparative Advantage Following (CAF) development strategy, Aid for Trade flows and structural change in production
}

\author{
Sèna Kimm Gnangnon * ${ }^{*}$
}

\author{
${ }^{*}$ Correspondence: \\ kgnangnon@yahoo.fr; \\ SenaKimm.Gnangnon@wto. \\ org \\ World Trade Organization, \\ Rue de Lausanne 154, \\ 1211 Geneva 21, Switzerland
}

\begin{abstract}
This article investigates empirically the interaction between countries' Comparative Advantage Following (CAF) development strategy and Aid for Trade (AfT) interventions in influencing the extent of structural change in production. Based on the Generalized Methods of Moments and an unbalanced panel dataset containing 81 countries over the period 1996-2016, the empirical exercise has shown that AfT flows are complementary with the CAF development strategy in generating a higher extent of structural change in production. Thus, higher amounts of AfT flows help promote structural change in production in countries that have adopted the CAF development strategy.
\end{abstract}

Keywords: CAF development strategy, CAD development strategy, Aid for Trade, Structural change in production

JEL Classification: F35, O11, O14, O2, O33, P59

\section{Introduction}

The terms "structure" and "structural change" (also referred to as "structural transformation") have yet been used with different meanings and interpretations in the economic literature, but they usually refer to long-term and persistent shifts in the sectoral composition of economic systems (Syrquin 2010). Since the first economic development theoreticians such as Paul Rosenstein-Rodan, Arthur Lewis and Albert Hirschman, structural change, broadly defined as the reallocation of resources away from agriculture and towards manufacturing, has been considered as the optimal path towards sustained economic growth (see for instance, Hansen and Prescott 2002). According to Matsuyama (2005, p. 1), structural change is multifaceted as it is a "complex, intertwined phenomenon", in which the income growth process and the various aspects of structural change like "sector composition .... organization of the industry, financial system, income and wealth distribution, demography, political institutions and even the society's value system", mutually affect and complement each other (see also Kuznets, 1972, 1973). The concept of structural change is also considered as having several dimensions, including changes in the composition of output, employment, exports and aggregate demand (see UNCTAD 2014, p. 60). The current article focuses 
on structural change in production, although the latter also encompasses structural change in employment (e.g., Fiorini et al. 2013). While the issue of structural transformation has been the subject of extensive research in the academic arena, it was largely absent in policymakers' circle. As noted by Losch et al. (2012), two factors have contributed to explaining the progressive political comeback of the focus on "structural change": first, the 2008 financial crisis raised questions about the sustainability of the existing growth model and its global imbalances; second, this financial crisis has demonstrated the limits of the market-only approaches, by showing that states have a key role to play, particularly in dealing with regulatory and structural issues. The need for state intervention in the market has been exemplified by the massive interventions of developed countries' governments to help cope with the adverse consequences of this crisis on their economies. The increasing attention being devoted to the importance of structural change at the regional and international levels is evidenced by the re-engagement of major development agencies and international institutions on long-term structural policies: for example, Justin Yifu Lin, previous Chief economist and Senior Vice President of the World Bank from 2008 to 2012, called for a "new structural economics" as a framework for rethinking development (Lin 2010); the International Monetary Fund (IMF) includes at the core of its agenda the issue of structural transformation and diversification in developing countries with a particular emphasis on Low-Income Countries. Structural change is also at the heart of the agenda of Regional development Banks such as the African Development Bank, the Asia Development Bank as well as international institutions such as UNIDO and UNCTAD. ${ }^{1}$

In the meantime, the development thinking literature has evolved significantly since the 1950s, from the old structuralism approach (e.g., Rosenstein-Rodan 1943; Lewis 1954; Hirschman 1958; Prebisch 1959, 1960)—which has underpinned the import substitution policies-to the Washington-Consensus policies (e.g., Williamson 1990, 2004) put forth by the Bretton Woods institutions, including the IMF and the World Bank. The New Structural Economics (NSE) has emerged in the development thinking literature as an alternative approach to development. This approach has received particular attention since the 2008 global financial crisis and the ensuing global recession (see Lin 2011). The NSE approach draws from the structural economics and the neoclassical approach (e.g., Lin 2011, 2012, 2015) to structure and change in the process of economic development, by emphasizing the importance of economic structure and industry upgrading. It views economic development as a dynamic process entailing structural changes and involving industrial upgrading and corresponding improvements in hard (or tangible) and soft (or intangible) infrastructure at each level (see Lin 2011, p. 194-195). As summarized by Bruno et al. (2015, p. 133), the NSE approach is a mixture of the structural approach to growth with neoclassical economics, and hence builds on three elements: an understanding of comparative advantages as the evolving potential of a country's endowment structure; a reliance on the market as allocation mechanism at any stage of development; and the importance of the role of the state in facilitating the process of industrial upgrading. At the heart of the NSE development approach is the idea that the economic structure

${ }^{1}$ It is worth noting that bilateral donors (including through their development agencies) have also been paying particular attention through different initiatives to the issue of structural transformation in developing countries. 
of an economy is endogenous to the structure of its factor endowments, and the basic mechanism for effective resource allocation is the market. In this context, the role of the state should be limited to providing information about the new industries, coordinating related investments across different firms in the same industries, compensating for information externalities, and nurturing new industries by incubating and encouraging foreign direct investment (see Lin 2011, p. 206). This approach, therefore, involves the Comparative Advantage Following (CAF) development strategy based on as opposed to the comparative advantage defying (CAD) development strategy. The CAF development strategy entails for a country to follow its comparative advantage when promoting industries. The CAD strategy involves developing advanced capital-intensive (heavy) industries that are not consistent with their comparative advantage, which is determined by their factor endowments. The CAF strategy requires that governments complement the role of the market mechanism in achieving the effective resource allocation by playing an active role in facilitating structural changes, including inter alia, by upgrading and improving hard and soft infrastructure. In view of the limited financial resources in developing countries to develop the requisite hard and soft infrastructure and eventually compensating for information externalities, we argue here that Aid for Trade (AfT) flows provided by donor-countries (as part of the overall official development assistance) could help recipient-countries' governments play their role in the NSE framework. AfT flows are part of overall official development assistance (ODA), the latter having been a subject of an immense empirical literature (e.g., Addison and Tarp 2015; Addison et al. 2017; Agénor and Aizenman 2010; Arellano et al. 2009; Chauvet and Ehrhart 2018; Lahiri 2006). Specifically, the AfT Initiative was launched at the 2005 WTO Hong Kong Ministerial Conference, and aims to help developing countries, particularly LDCs, to build the supply-side capacity and trade-related infrastructure that they need to assist them to implement and benefit from WTO Agreements and more broadly to expand their trade (see WTO Secretariat document WT/MIN(05)/DEC).

The current paper investigates empirically not only the effect of the CAF/CAD development strategies on structural change in production in developing countries, but also how Aid for Trade flows (i.e., AfT interventions) interact with these strategies in influencing the extent of structural change in production in these countries. The analysis has used two measures of structural change across several production sectors in the economy. The first indicator is derived from a metric-based approach, and relies on the Norm and Absolute Value Index. The second measure is the Modified Lilien Index of structural change. Sectors of the economy over which the structural change in production has been examined include Sector 1 (Agriculture, hunting, forestry and fishing); Sector 2 (Manufacturing); Sector 3 (Mining and utilities) and Sector 4 (Services).

In the existing literature, many studies have now investigated the macroeconomic impact of the CAF/CAD development strategy including for example, in terms of economic growth (Bruno et al. 2015); economic growth and growth volatility (Lin 2012); inclusive growth (Lin 2004); inequality (Chen and Lin 2008); and poverty (Siddique 2015). On the other hand, while there is now an important literature on the effectiveness of AfT (Cirera and Winters 2015; Ghimire et al. 2013, 2016; Gnangnon 2019; Hühne et al. 2014a, b; Martínez-Zarzoso et al. 2017; see a literature review in OECD/ 
WTO 2017), to the best of our knowledge, only one study ${ }^{2}$ (Cirera and Winters 2015) has looked at the structural change effect of Aid for Trade programmes. However, this study has focused on structural change in exports-and not on structural change in production. Specifically, Cirera and Winters (2015) have assessed whether AfT programmes have assisted the process of structural transformation in sub-Saharan African (SSA) countries. They have examined the existence of an indirect impact of AfT flows on structural change through the trade flows and trade costs effects of AfT. They have obtained empirical evidence of no significant impact of AfT flows on trade costs, aggregate flows, bilateral trade flows and sector trade flows, with the exception that AfT programmes on trade policy and regulations reduce the time to export and import. Second, they have additionally examined the impact of AfT on structural change indicators and found no statistically significant effect.

The empirical exercise in the current article uses a panel dataset comprising 81 countries over the period 1996-2016. Results based on the two-step system GMM approach suggest that total AfT flows are complementary with the CAF development strategy in generating a higher extent of structural change in production.

The remainder of the paper is structured around five sections. Section 2 discusses how AfT flows and the CAD/CAF development strategy interact in influencing the extent of structural change in production. Section 3 lays down the model specification that helps address empirically the questions at hand. Section 4 discusses the econometric strategy, and Sect. 5 interprets the empirical results. Section 6 concludes.

\section{CAF/CAD strategy, Aid for Trade and structural change in production}

The NSE approach makes a distinction between the CAF development strategy and the CAD development strategy. Countries that implement the CAD strategy promote the development of advanced capital-intensive (heavy) industries that are not consistent with their comparative advantage, which is determined by their factor endowments. This involves for example, providing non-viable firms with subsidies (e.g., through fiscal transfers) and protections. This makes the CAD industries non-viable in open and competitive markets (Lin 2011). In contrast, the implementation of the CAF development strategy (i.e., by following the comparative advantage when promoting industries) makes economies highly competitive in the domestic and world markets, and enjoy the largest possible market shares. Furthermore, the proponents of the CAF development strategy have argued that this strategy results in a faster upgrade of the country's structure of factor endowments and allows enterprises to reduce their industrial technological gap vis-à-vis developed countries, including by acquiring from developed countries industrial and technological innovations that match with their new comparative advantage. Rodrik (2011) has welcomed the NSE approach advocated by Lin (2011). He has noted many areas of agreement with Lin's theory, and few areas of differences that he has suspected as 'methodological' and perhaps even just 'terminological' differences, which may have little practical impact (see Rodrik 2011, p. 229). However, the CAD development strategy has received support in the literature (see UNCTAD 2016), the

${ }^{2}$ It is worth noting that few studies have examined the effect of official development assistance (ODA), which includes Aid for Trade, on structural change (e.g., Page 2012; Ahlerup 2019). 
argument being that developing countries are endowed with abundant cheap labourintensive industries, and hence can compete in the global market of these industries. Another argument put forth has been that a CAF strategy would constrain countries to specialize in sectors of static comparative advantage, which in developing countries, represent low-value added and low-productivity sectors where possibilities for learning and upgrading are limited. Along these lines, Chang (1994) has stated that industrial policy involves building comparative advantages and creating entirely new sectors and industries rather than following static comparative advantages. Thus, industrial policy should help countries promote and discover their dynamic comparative advantage (see UNCTAD 2016). Fine and Waeyenberge (2013) have called into question the NSE approach, and noted that its core theoretical notion of comparative advantage is flawed. They have stressed the commitment of this approach to a flawed and an incoherent application of the neoclassical economics, with a narrow policy scope. Another strand of the literature has discussed the disadvantages of so-called CAF-led growth owing to different initial conditions between trading countries. The core-periphery arguments ${ }^{3}$ are strictly based on how productivity enhancement in the core affects employment and terms of trade in the periphery requiring these countries to adjust beyond what the natural comparative advantage would suggest (e.g., Acharyya and Kar 2014). In fact, most developing countries leapfrogged on account of such concerns, wherein the adjustments were rapid, showed structural breaks, and led to abrupt relocation of factors of production.

In light of this discussion, the current analysis does not intend to argue with certainty that the NSE approach is the right one for all countries, in particular developing countries. Rather, it aims to test whether this approach is related to structural change in production, including in conjunction with AfT flows. Nonetheless, in light of the findings in the existing literature that the CAF development strategy promotes economic growth (e.g., Bruno et al. 2015; Lin 2012) and reduces growth volatility (Lin 2012), enhances inclusive growth (Lin 2004) and helps reduce poverty (Siddique 2015), we are tempted to argue that countries that adopt a CAF strategy could experience a higher extent of structural change in production, given that the CAF development strategy would help them progressively move towards activities of high value addition, including in line with the dynamic change in their factor endowments. We do not however exclude the possibility that the empirical exercise would show a negative effect or statistically nil effect of the CAF development strategy on the extent of structural change in production, including in the presence of higher AfT flows.

Let us now discuss how AfT could affect the extent of structural change in production. The literature on the effectiveness of AfT has considered three categories of AfT flows (as defined by the Organization for Economic Cooperation and Development, OECD). These include AfT flows for building economic infrastructure; AfT flows for strengthening productive capacity; and AfT flows related to trade policies and regulations. Therefore, the effect of total AfT flows on structural change in production would depend on how each of these components of total AfT flows influences

\footnotetext{
${ }^{3}$ We thank a Reviewer for suggesting making reference to this strand of the literature.
} 
the extent of structural change in production. AfT interventions that allow building economic infrastructure could help reduce production costs, including the costs associated with intermediate inputs used in the production process of final products. Hence, this type of AfT flows would induce a higher extent of structural change in production across sectors in the economy. Nevertheless, as these effects are indirect (they do not target a specific sector), they could be sector-neutral. As noted by Cirera and Winters (2015), in the absence of large sector distortions, these interventions may favour sectors of comparative advantage, and hence induce a lower extent of structural change in production, that is, a concentration of production on sectors of comparative advantage in the economy. AfT interventions related to trade policy and regulations could contribute to reducing administrative costs and regulatory bottlenecks to trade (Busse et al. 2012; Calì and TeVelde 2011). In particular, such AfT interventions could, inter alia, allow policymakers to be better equipped with the appropriate trade policies consistent with the eventual government's strategy of promoting structural change. Notwithstanding this, for LDCs, unless the "self-reinforcing (lock-in) effects of initial specialization" makes it difficult for them to diversify and promote structural change in production, we could expect this indirect effect of AfT for trade policy and regulations to positively influence structural change in production, through production diversification away from primary products to manufacturing products and/or services. AfT interventions directed toward specific sectors, which as we will see later on, are categorized under the umbrella term "Aid for Trade for productive capacity" aim to strengthen capacity in sectors such as banking and financial services, business and other services, agriculture, fishing, industry, mineral resources and mining, and tourism. Such interventions would have a direct effect on structural change in production in the recipient country, including by promoting or reducing the extent of structural change in production, depending on the strategy implemented by the beneficiary country, i.e., on whether or not the latter relies on its sectors of comparative advantage. Overall, as AfT interventions are consistent with the development strategy of the recipient-countries, we expect that they could positively or negatively influence the extent of structural change in production.

Now, let us consider how could the CAF/CAD development strategy interact with AfT interventions in influencing the extent of structural change in production in the recipient-countries? Based on the NSE framework, we postulate that Aid for Trade flows could help governments complement the market mechanism role (i.e., achieving an effective resource allocation) in facilitating structural change by, inter alia, helping upgrade and improve hard and soft infrastructure, and eventually compensate for information externalities. In that context, AfT interventions could contribute to laying the ground for the implementation of a CAF strategy that would help recipient-countries promote structural change in production, in line with their overall development strategies. Therefore, we expect greater AfT flows to be complementary with the CAF development strategy in promoting structural change in production. The empirical exercise would help test this hypothesis and provide clear evidence on whether AfT flows and CAF development strategy are complementary or substitutable in promoting the extent of structural of production. 


\section{Empirical model}

We examine the effect of both CAF/CAD development strategy, and AfT on structural change in production by drawing from the relatively scant literature on the macroeconomic determinants of structural change (e.g., Dabla-Norris et al. 2013; Duarte and Restuccia 2010; McMillan et al. 2014; Jha and Afrin 2017; Herrendorf et al. 2014; Martins 2018). In addition to the two variables of interest in the analysis, namely Aid for Trade and the indicator of the development strategy based on comparative advantage, the analysis also considers a number of control variables that are expected to influence the effect of these two variables of interest on the dependent variable. These controls include the trade policy stance ("TP"); the development level ("GDPC") measured by the real per capita income, which also captures the domestic demand pattern; the education level ("EDU"); the financial development depth (denoted "FINDEV"); countries' physical fundamentals, such as the share of arable land in total land in a given country ("SHARABLE"), the population size ("POP"), and the institutional and governance quality ("INST").

Dabla-Norris et al. (2013) have examined the determinants of structural change in production by using countries' fundamentals as well as policy and institutional factors to explain the differences in output structures. In particular, the authors have documented stylized facts on the process of structural transformation around the world by using output shares (sectoral real value added by economic activity, including agriculture, manufacturing and services) as a proxy for structural change. Along the same lines, Jha and Afrin (2017) have examined the patterns of structural transformation in African countries, including by considering the evolution and determinants of the shares of agricultural, manufacturing and services in total output for 53 African countries. McMillan et al. (2014) have subsequently considered the determinants of structural change, but also provided empirical evidence that structural change contributed positively to Africa's overall productivity growth. The authors have proxied structural change by the labour reallocation effect. Specifically, using data on economy-wide, and sectoral labour productivity, the authors have decomposed the change in the economy-wide productivity into two components. The first component is the "within" component of productivity growth, i.e., the weighted sum of productivity growth within individual sectors, where the weights are the employment share of each sector at the beginning of the time-period. The second component referred to as "structural change" term reflects the productivity effect of labour re-allocations across different sectors. In the spirit of the work by McMillan et al. (2014), Martins (2018) has examined the determinants and patterns of structural change by using the Shapley decomposition developed by Shorrocks (2013) to extract the indicator of structural change. Herrendorf et al. (2014) have studied structural transformation by developing a multi-sector extension of the one-sector growth model (that encompasses the main existing theories of structural transformation), which serves as a natural benchmark to study structural transformation and that it is able to account for many salient features of structural transformation. Duarte and Restuccia (2010) have developed a model to measure structural transformation so as to examine the role of structural transformation (the secular reallocation of labour across sectors) on aggregate productivity. 
The current analysis has used two measures of the extent of structural change in production across several production sectors in the economy. The first and main measure (henceforth referred to as SCINAV) is a metric-based structural change index, which relies on the Norm and Absolute Value Index. The second indicator used for robustness check analysis is the Modified Lilien Index of structural change, henceforth referred to as SCIMLI. Both indicators have been computed using the disaggregation of United Nations Data on Sectoral Value Added. In particular, we use the following sectoral disaggregation (four sectors are considered). Sector 1: agriculture, hunting, forestry and fishing; Sector 2: manufacturing; Sector 3: mining and utilities and Sector 4: construction, wholesale, retail trade, restaurants and hotels, transport, storage and communication and other activities, which we sum up to obtain the "Service" sector.

The SCINAV indicator, which has also been used in other studies (e.g., Productivity Commission 1998; Bacchetta and Jansen 2003; Cortuk and Singh 2011; Dietrich 2012; and Fiorini et al. 2013) reflects the extent of structural change across several production sectors in the economy. In the literature, it is also referred to as the Michaely Index (Michaely 1962) or Stoikov Index (Stoikov 1966). It is the most prominent and also simplest measure of structural change, and is derived from a metric-based approach of measuring structural change. It summarizes here the changes in sectoral composition of an economy between two points in time.

The SCINAV indicator is defined as follows: SCINAV $=0.5 \sum_{i=1}^{n}\left|x_{i t}-x_{i s}\right|$, where $x_{i t}$ is the share of sector $i$ at time $t$ and $x_{i s}$ is the share of sector $i$ at time $s$. Hence, the differences of the sector shares $x_{i}$ are first calculated between two points in time ( $s$ and $t$ ). The absolute amounts of these differences are summed up and divided by two (since each change is counted twice). The SCINAV indicator has been computed using non-overlapping 3-year averages of data on sectoral shares (of total output) in order to capture medium term effects over the period 1996-2016 (see the sub-periods below). As such, the SCINAV values range between zero and unity, which facilitates its interpretation. For example, the amount of structural change exactly equals the share of the movements of the sectors as a percentage of the whole economy (see Dietrich 2012). If the structure remains unchanged, the index is equal to zero, and if the whole economy undergoes a total change (the change in all sectors is at its highest), then the index is equal to unity.

The Modified Lilien Index of structural change (SCIMLI) is derived from an axiomatic analysis of SCI (see details on Dietrich 2012). The Lilien (1982) Index originally measured the standard deviation of the sectoral growth rates of employment from period $\mathrm{s}$ to period t. Stamer (1998) modified this index in order to fulfil the characteristics of a metric. The SCIMLI indicator is defined as follows: SCIMLI $=\sqrt{\sum_{i=1}^{n} x_{i t} \cdot x_{i t^{\prime}} \cdot\left(\ln \frac{x_{i t}}{x_{i t^{\prime}}}\right)^{2}}$, with $x_{i t}>0$ and $x_{i t^{\prime}}>0 . x_{i t}$ is the share of sector $i$ at time $t$ and $x_{i t^{\prime}}$ is the share of sector $i$ at time $t^{\prime}$. According to this index, the influence of sector $i$ grows in proportion to its size as well as to the value of its relative growth. Like for the SCINAV indicator, the SCIMLI indicator has also been computed using non-overlapping 3-year averages of data on sectoral shares so as to capture medium term effects. A rise in the values of SCINAV and SCIMLI indicators reflects a greater extent of structural change across production sectors, while a decrease in the values of these indicators indicate a lower extent of structural change across production sectors. 
The variable "TCI" stands for the proxy for the development strategy based on comparative advantage (i.e., CAF or CAD) adopted by a given country (see for example Lin and Liu, 2004 and Bruno et al. 2015). Following for example, Lin and Liu (2004) and Bruno et al. (2015), we calculate TCI using the formula: $\mathrm{TCI}_{i t}=\frac{\mathrm{AVM}_{i t} / \mathrm{LM}_{i t}}{\mathrm{GDP}_{i t} / \mathrm{L}_{i t}}$, where $\mathrm{AVM}_{i t}$ is the added value of manufacturing industries of a given country $\mathrm{i}$, at time $\mathrm{t}$; $\mathrm{GDP}_{i t}$ is the total added value of the country $\mathrm{i} ; \mathrm{LM}_{i t}$ stands for the labour in the manufacturing industry, and $\mathrm{L}_{i t}$ is the total labour force. For a given country, a rise in the values of the TCI indicator reflects the fact that this country follows a CAD development strategy by investing in heavy (capital-intensive) manufacturing industries, whereas declining values indicate that the country follows a CAF development strategy. The numerator of the TCI (i.e., $\mathrm{AVM}_{i t} / \mathrm{LM}_{i t}$ ) is relatively larger when manufacturing firms experience large market shares due to the government's intervention (with access to subsidized credit and inputs, and very high profits lead to higher investment into capital) and as a result, where the value added generated by the sector is above what would be generated otherwise. Concurrently, as such a strategy leads to a distorted sector where capital-intensive technologies are the government's priority, the sector would employ less labour. As noted by Bruno et al. (2015, p. 134), the TCI indicator reflects a situation where a government tries to kick-start economic growth through policies supporting a capital-intensive manufacturing sector.

The variable "AfT" is the measure of the real gross disbursements of AfT flows. It could either be real total gross disbursements AfT flows (constant US dollar 2016 prices), and denoted "AfTTOTCST" or its components, namely the real gross disbursements Aid for Trade flows for economic infrastructure (constant US dollar 2016 prices) denoted "AfTINFRACST", the real gross disbursements of Aid for Trade flows for building productive capacity (constant US dollar 2016 prices) denoted "AfTPRODCST", and the real gross disbursements of Aid for Trade flows allocated for trade policies and regulations (constant US dollar 2016 prices) denoted "AfTPOLCST". Data on gross disbursements of AfT is available in OECD/CRS database from 2002 onwards. In particular, when the current study was being written, the data available covered the period 2002-2016. As this period is relatively short to capture the extent of structural change in production (it takes time for countries to change the sectoral structure of output) in AfT recipient countries, we rely on AfT commitment data that covers the period 1995 onwards, and adopt the approach used in Selaya and Sunesen (2012, p. 2158) to expand our AfT data so that it covers now the period 1996-2016 (this approach has also been used in Clemens et al. 2012; Thiele et al. 2006). The approach assumes that the proportion of AfT actually disbursed to sector " $x$ " ( $\left.\mathrm{AfT}_{x}\right)$ (for example, AfT disbursed for economic infrastructure; productive capacity building; and trade policies and regulations) during a given period is equal to the proportion of aid committed to sector $x$ during this period, and is hence given by AfT $\mathrm{A}_{x}=\frac{\text { Commit }_{x}}{\sum_{x} \text { Commit }_{x}} \sum_{x} \mathrm{AfT}_{x}$, where Commit $x$ stands for the amount of real AfT commitments (constant US dollar 2016 prices) to sector $\mathrm{x} ; \sum_{x} \mathrm{AfT}_{x}$ is the total amounts of AfT commitments and disbursements (constant US dollar 2016 prices) received during each period, respectively. While there may be some concerns about the approximation of sectoral disbursements with sectoral commitments because of differences in definitions and statistical record (see Clemens et al. 2012 for more details), Odedokun (2003) and 
Clemens et al. (2012) have noted that this problem is likely to be small since aid disbursements and commitments (both on the aggregate and sectoral levels) are highly correlated. Using this formula and based on AfT commitments and disbursements (constant US dollar 2016 prices) extracting from the OECD/CRS database (see Appendix 1 for more details), we have calculated for each country in the sample, and for each year, from 1996 to 2001, data on gross disbursements of AfT for economic infrastructure, gross disbursements of AfT for productive capacity building, and gross disbursements of AfT for trade policies and regulations. This data has been merged with the available dataset on OECD/ CRS database on these three types of AfT flows over the period 2002-2016, so as to obtain the dataset of 81 countries over the period 1996-2016, used in the current analysis.

Against this background, we posit the following model:

$$
\begin{aligned}
\log (\mathrm{SCI})_{i t}= & \varphi_{0}+\varphi_{1} \log (\mathrm{SCI})_{i t-1}+\varphi_{2} \mathrm{TCI}_{i t}+\varphi_{3} \log (\mathrm{AfT})_{i t}+\varphi_{4} \mathrm{TP}_{i t} \\
& +\varphi_{5} \mathrm{EDU}_{i t}+\varphi_{6} \log (\mathrm{GDPC})_{i t}+\varphi_{7} \mathrm{FINDEV}_{i t}+\varphi_{8} \log (\mathrm{POP})_{i t} \\
& +\varphi_{9} \mathrm{SHARABLE}_{i t}+\varphi_{10} \mathrm{INST}_{i t}+\vartheta_{i}+\omega_{t}+\varepsilon_{i t},
\end{aligned}
$$

where $i$ represents a country's index; $t$ denotes the time-period. The panel dataset used to estimate model (1) contains 81 AfT recipients over the period 1996-2016. The variable "SCI" is the dependent variable, which is primarily measured by the indicator "SCINAV", and for robustness check by the indicator "SCIMLI". "TCI" is the indicator of the development strategy. "AfT" is the measure of real gross disbursements of AfT flows. The description and source of all control variables are provided in Appendix 1. Data on variables has been averaged over non-overlapping sub-periods of 3-year average so as to reduce the influence of business cycles on variables, as well as to obtain medium-term effects of regressors on the dependent variable. The sub-periods include 1996-1998; 1999-2001; 2002-2004; 2005-2007; 2008-2010; 2011-2013; and 2014-2016. The dependent variable "SCI" represents the extent of structural change in production. We have applied the natural logarithm to this variable so as to limit its high skewness. Likewise, the natural logarithm has been applied to the variables "AfT", "GDPC", and "POP" in order to limit their high skewness. The one-period lag of the dependent variable has been included in model (1) as a regressor so as to capture the initial level of structural change in production as well as the persistence of this variable over time. Model (1) features countries' fixed effects $\left(\vartheta_{i}\right)$ and time effects $\left(\omega_{t}\right)$. The latter represent global shocks that could affect the process of structural change in production in all countries together. $\varphi_{0}$ to $\varphi_{10}$ are parameters to be estimated. $\varepsilon_{i t}$ is an error term. Appendix 2 shows descriptive statistics on the variables used in the analysis, while Appendix 3 presents the list of countries used in the analysis.

We shed light on how the key variables of interest, namely structural change indices (SCINAV and SCIMLI), TCI and the total AfT flows, in constant values (AfTTOTCST), have evolved over the period 1996-2016. To do so, we use the 3-year average data to provide in Fig. 1 the evolution of the two indices of structural change in production and TCI, while Fig. 2 displays the evolution of the two indices of structural change in production as well as the total real AfT flows. Furthermore, Fig. 3 has used SCINAV as the measure of structural change in production (which is our primary measure of structural change in production), and shows the correlation pattern (in the form of scatter plot) between 

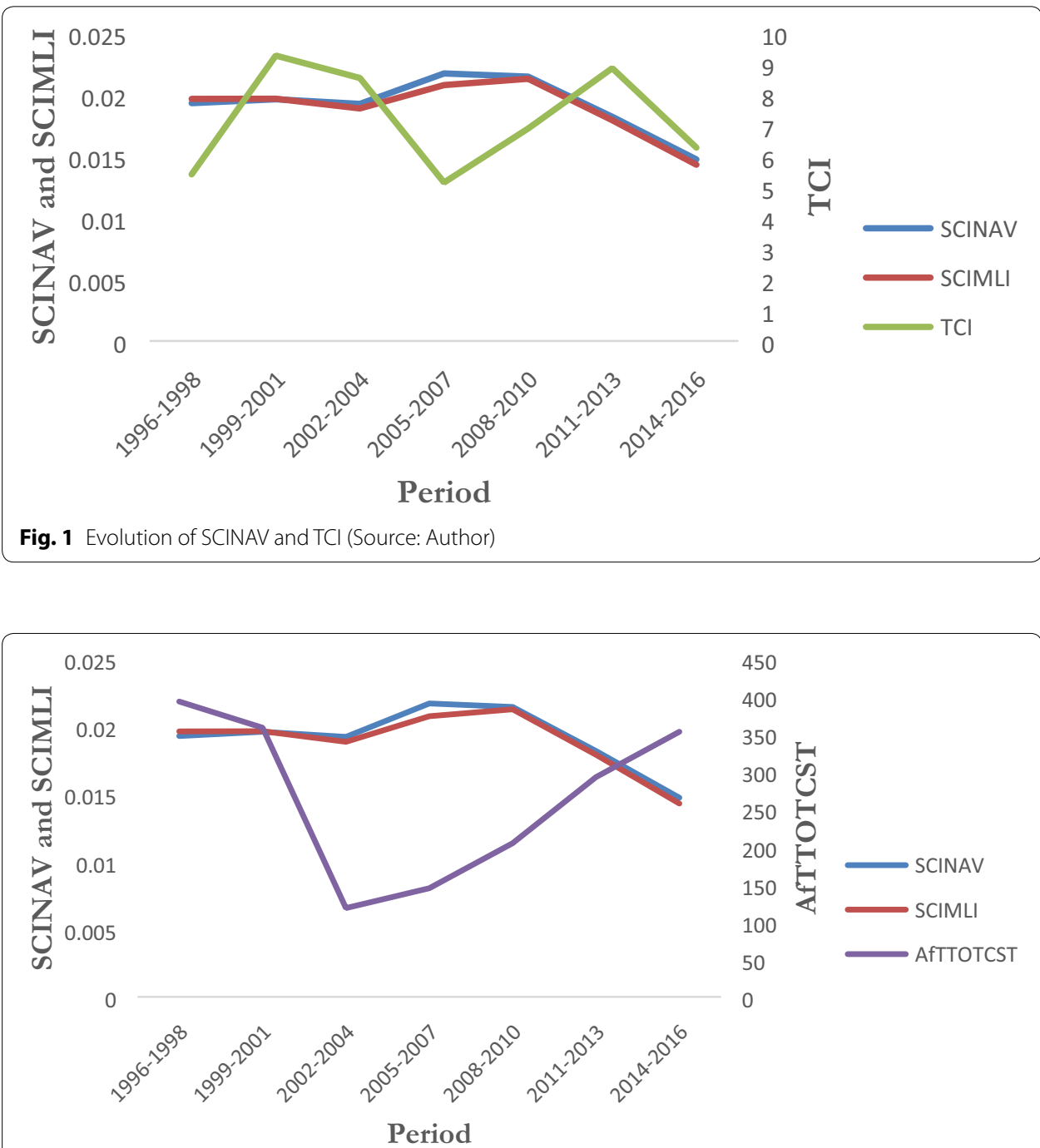

Fig. 2 Evolution of SCINAV and AfTTOTCST. Total Aid for Trade (AfTTOTCST) is expressed in millions US Dollars, constant 2016 prices (Source: Author)

this variable and TCI on the one hand, and between SCINAV (in Logs to limit its skewness) and the total real AfT flows (also in Logs to limit its skewness), on the other hand. We observe in Fig. 1 that the developments of SCINAV and SCIMLI are quite similar: the two indices (the extent of structural change in production) have remained relatively stable from 1996-1998 to 2002-2004, but have declined from 2002-2004 to 2008-2010. They have subsequently decreased from 2008-2010 to 2014-2016, thereby reflecting a decline in the extent of structural change in production. Likewise, the TCI indicator has increased from 5.4 in 1996-1998 to 8.5 in 2002-2004 (which reflects a tendency for the adoption of a CAD development strategy), and subsequently declined to reach 5.14 in 2005-2007 (thereby suggesting the adoption of a CAF strategy). From 2008-2010 to 2011-2013, values of TCI have risen from 6.9 to 8.8, and then fallen to 6.3 in 2014-2016. Overall, TCI and the extent of structural change indicators have not always evolved in the same direction over the period 1996-2016. It is worth noting that as per statistics 


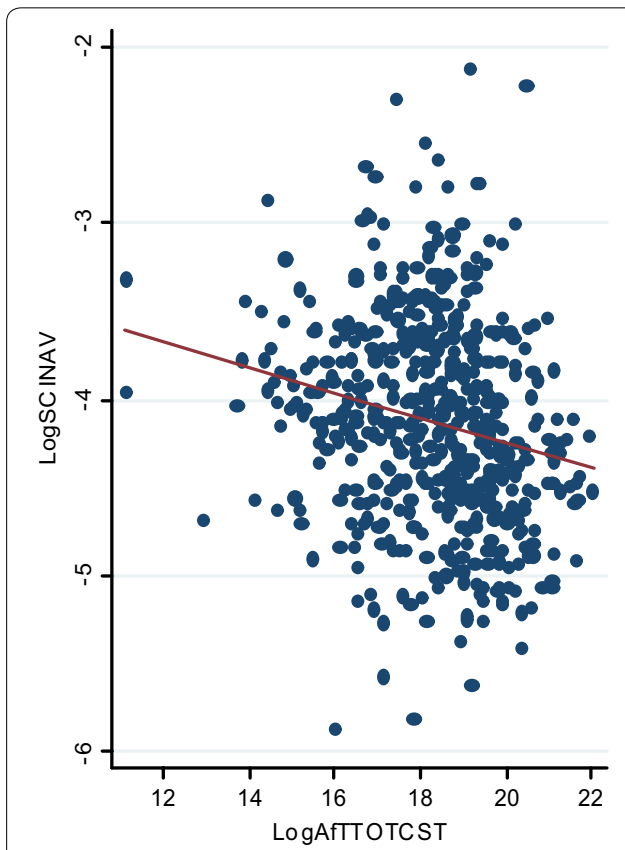

- LogSCINAV Fitted values

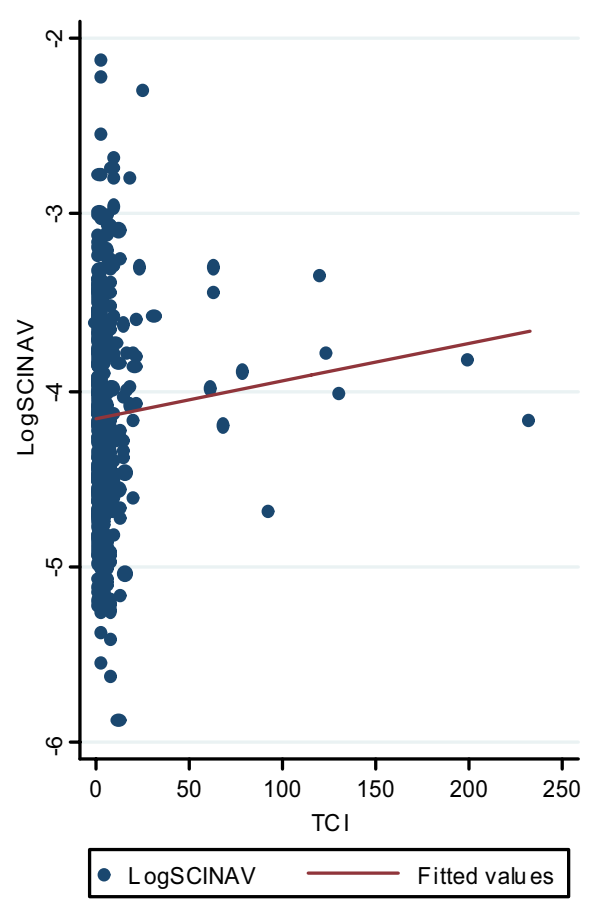

Fig. 3 Correlation pattern between SCNAV (in Logs), TCl, and AfTTOTCST (in Logs) Source: Author

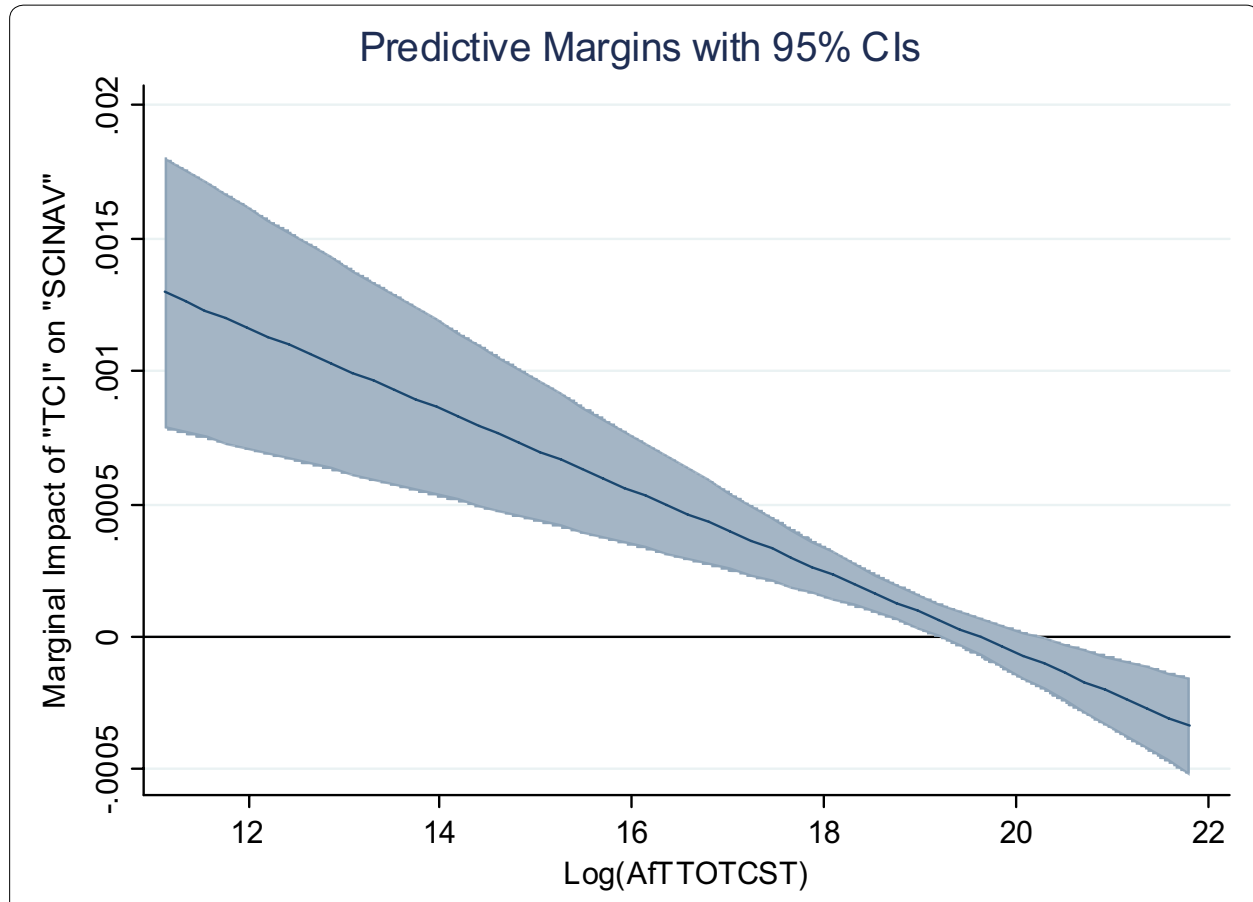

Fig. 4 Marginal impact of "TCI" on "SCINAV", for varying amounts of total AfT (Source: Author)

reported in Appendix 2, we note that values of TCI range between 0.475 (for Tunisia in the sub-period 2014-2016) to 231.7 for (for Niger in the sub-period 2002-2004) (Fig. 4).

Figure 2 suggests that the total real AfT flows and structural change in production indicators have evolved in opposite directions. In particular, AfT flows have declined from US\$ 392 
million in 1996-1998 to US\$ 118.1 million in 2002-2004. Real AfT flows have subsequently embraced a rising trend from 2005 onwards-from 2007-2009 to 2014-2016-(i.e., after the launch of the AfT Initiative in 2005). Finally, with regard to Fig. 3, we observe in the left-hand graph a negative correlation pattern between the total real AfT flows and SCINAV, and in the right-hand graph a positive correlation pattern between TCI and SCINAV. These tend to indicate that AfT flows are associated with a lower extent of structural change in production, while the CAD strategy is correlated with a higher extent of structural change in production. However, these patterns reflect simple correlations, but not causality.

\subsection{Expected effects of control variables}

We expect greater trade policy liberalization to be conducive to structural change in production through, inter alia, the diffusion of knowledge and technology from the direct import of high-tech goods and higher productivity (e.g., Grossman and Helpman 1991; Barro and Sala-i-Martin 1997; Baldwin et al. 2005) that would promote output and employment in high-productivity sectors. However, if greater trade policy liberalization leads countries to lock their production into sectors in which they have a comparative advantage (which is particularly the case for poor countries exporters of primary products), this would likely result in lower extent of structural change in production. Real per capita income (which acts as a measure of development level) is likely positively associated with the extent of structural change, as richer countries have a greater capacity, including human, physical and productive capacities to promote structural change in production compared to relatively less advanced countries. Human capital characteristics, including the education level reflects the average skill level of the workforce, and could induce a greater extent of structural change in production if this workforce is used in a wide range of high value-added productive sectors. However, if the bulk of existing workforce is used in existing activities (e.g., Agosin et al. 2012), this might result in lower extent of structural change in production. Limited access to affordable finance would constrain the ability of firms to produce and generate higher employment growth (Martins 2018), which would reduce the extent of structural change in production. A rise in the depth of financial development could allow greater diversification, risk sharing, and investment in higher productivity activities, and hence facilitate resource allocation across the economy (Levine 2005). This could, in turn, facilitate the development of activities with high value addition, and promote structural change in production across the various sectors of the economy. In the meantime, one could expect financial development to be associated with a lower extent of structural change in production (i.e., for example a concentration of production activities in few sectors of the economy) if banks are willing to finance only the development of activities in which the country has a comparative advantage. The size of the population aims to capture possible scale effects that can affect structural change in production. Countries' fundamentals are captured through the inclusion of the share of arable land in total land in model (1).

Weak institutions divert resources from productive sectors to unproductive sectors, and hence promote rent-seeking activities (Iqbal and Daly 2014). Similarly, widespread corruption, inefficient bureaucracy, and a high risk of expropriation of private property by the government can create uncertainty among producers and discourage them from investing and innovating over the long term (Faruq 2011). In this context, better 
governance and institutional quality would be positively associated with the extent of structural change in production. However, better institutional and governance quality might be associated with a lower extent of structural change in production (i.e., a concentration of production in few production sectors of the economy) if countries' activities are developed in sectors of comparative advantage.

\section{Method}

The empirical exercise starts with the estimation of model (1) (without the one-period lag of the dependent variable as a regressor) using standard estimators. The first set of estimators include the pooled ordinary least-squares (denoted "POLS-DK") and the fixed effects estimator (denoted "FE-DK"), where standard errors have been corrected using the Driscoll and Kraay (1998) technique. The other estimators are the random effects (denoted "RE") and the feasible generalized least squares estimator (denoted "FGLS"). It is important to note that the Driscoll and Kraay (1998) technique allows for correcting standard errors for heteroscedasticity, autocorrelation and cross-sectional dependence. Results of these estimations are presented in Table 1. However, these results could be biased for several reasons. First, there could be a bi-directional causality between the dependent variable and a number of regressors, including Aid for Trade flows, the indicator of the CAF/CAD development strategy, trade policy, the education level, and the

Table 1 Effect of AfT flows and development strategy on structural change in production

\begin{tabular}{|c|c|c|c|c|}
\hline \multirow[t]{3}{*}{ Variables } & POLS-DK & FE-DK & RE & $\begin{array}{l}\text { FGLS with panel- } \\
\text { specific AR(1) }\end{array}$ \\
\hline & $\log (\mathrm{SCINAV})$ & $\log (\mathrm{SCINAV})$ & $\log (\mathrm{SCINAV})$ & $\log (\mathrm{SCINAV})$ \\
\hline & (1) & (2) & (3) & (4) \\
\hline $\mathrm{TCl}$ & $\begin{array}{l}-0.00117 \\
(0.000502)^{* *}\end{array}$ & $\begin{array}{l}-0.00458 \\
(0.00137)^{* * *}\end{array}$ & $-0.00118(0.000996)$ & $\begin{array}{l}-0.000865 \\
(0.000413)^{* *}\end{array}$ \\
\hline $\log ($ AfTTOTCST) & $-0.0153(0.0134)$ & $-0.000102(0.0171)$ & $0.00214(0.0282)$ & $-0.00770(0.00724)$ \\
\hline $\mathrm{TP}$ & $-0.000866(0.00193)$ & $0.000633(0.00126)$ & $0.000240(0.00317)$ & $0.000217(0.00142)$ \\
\hline EDU & $\begin{array}{l}-0.00674 \\
(0.00191)^{* * *}\end{array}$ & $\begin{array}{l}-0.00332 \\
(0.00122)^{* * *}\end{array}$ & $\begin{array}{l}-0.00445 \\
(0.00193)^{* *}\end{array}$ & $\begin{array}{l}-0.00603 \\
(0.000487)^{* * *}\end{array}$ \\
\hline $\log (G D P C)$ & $0.0477(0.0279)^{*}$ & $-0.372(0.0456)^{* * *}$ & $0.0267(0.0541)$ & $0.0677(0.0126)^{* * *}$ \\
\hline FINDEV & $\begin{array}{r}-0.000353 \\
(0.000882)\end{array}$ & $0.00186(0.00132)$ & $0.000645(0.00126)$ & $0.000466(0.000709)$ \\
\hline $\log (P O P)$ & $-0.175(0.0139)^{* * *}$ & $-0.216(0.278)$ & $-0.172(0.0289)^{* * *}$ & $-0.195(0.00760)^{* * *}$ \\
\hline SHARABLE & $\begin{array}{l}0.00385 \\
(0.000416)^{* * *}\end{array}$ & $0.0174(0.00770)^{* *}$ & $0.00209(0.00365)$ & $0.00520(0.00121)^{* * *}$ \\
\hline INST & $-0.171(0.00583)^{* * *}$ & $-0.101(0.0615)$ & $-0.164(0.0463)^{* * *}$ & $-0.192(0.0144)^{* * *}$ \\
\hline Constant & $-0.948(0.272)^{* * *}$ & $2.221(4.776)$ & $-1.348(0.762)^{*}$ & $-1.074(0.235)^{* * *}$ \\
\hline $\begin{array}{l}\text { Observations-coun- } \\
\text { tries }\end{array}$ & $388-81$ & $388-81$ & $388-81$ & $382-75$ \\
\hline$R$-squared & 0.309 & & & \\
\hline Within $R$-squared & & 0.0724 & 0.1075 & \\
\hline Between $R$-squared & & & 0.4077 & \\
\hline Overall $R$-squared & & & 0.3172 & \\
\hline
\end{tabular}

Estimators: POLS-DK; FE-DK; RE; and FGLS

Robust standard errors are in parenthesis. For the random effects estimator, standard errors are clustered at the country level. Time dummies have been included in the regressions using the random effects estimator

${ }^{*} p$ value $<0.1 ;{ }^{* *} p$ value $<0.05 ;{ }^{* * *} p$ value $<0.01$ 
depth of financial development. Second, there might be another endogeneity concern associated with the absence of the one-period lag of the dependent variable as a regressor (i.e., the omitted variable bias). Furthermore, the presence of one-period lag of the dependent variable as a regressor in model (1) could induce another endogeneity bias due to the correlation between the unobserved country-specific effects and the lag(s) of the dependent variable (e.g., Nickell 1981; Anderson and Hsiao 1982). To address these endogeneity problems, we use the two-step system GMM estimator (see Arellano and Bover 1995; Blundell and Bond 1998) to estimate model (1) as it stands, as well as various other specifications of this model. This estimator is particularly appropriate for panel dataset like the one used in the current study, i.e., with large $\mathrm{N}$ (number of individuals) and small $\mathrm{T}$ (time-period). In spite of the fact that the full exogeneity of the GMM-type instruments has been questioned in the empirical literature, this estimator is largely used in empirical studies given its superior small sample properties (for example, compared to the first difference-GMM approach of Arellano and Bond 1991; and the one-step system GMM approach) notably when the series are highly persistent over time (see Blundell et al. 2001). To address endogeneity concerns, the estimation based on the two-step system GMM approach uses lagged values as instruments for the first-differenced regressors, and first-differences as instruments for the equation levels. AfT variables (i.e., the variable capturing the total AfT flows and its components) as well as regressors "TCI", "TP", "EDU", and "FINDEV" have been considered as endogenous in the regressions based on the two-step system GMM estimator. The validity of the two-step system GMM estimator depends on the assumption that idiosyncratic disturbances do not show significant second-order serial correlation $(\operatorname{AR}(2))$ in the error term, but a significant first-order serial correlation in the error term (AR(1)), along with the Sargan test for over-identification, whose statistic is expected to show a $p$ value higher than $10 \%$. We also report results associated with the test of third-order serial correlation in the error term $(\operatorname{AR}(3))$, which is expected to show a statistic whose p-value should be higher than $10 \%$. Finally, we present the number of instruments used in the regressions, as a number of instruments higher than the number of countries could make the afore-mentioned tests irrelevant (Roodman 2009). In the regressions, we have used a maximum of 2 lags of dependent variable as instruments and 2 lags of endogenous variables as instruments.

Tables 2, 3, 4, 5 present the outcomes of estimations of different variants of model (1) using the two-step system GMM estimator. Specifically, Table 2 presents results arising from the estimation of model (1) that helps examine the effect of total AfT flows and the TCI indicator on the extent of structural change in production (see columns [1], [2] and [3]). Table 3 reports the outcomes of the estimations of specifications of model (1) where the variable capturing the total AfT flows is replaced with each of its components. Table 4 displays the estimates arising from the estimation of model (1). These estimates allow to examine how AfT flows and the CAF/CAD development strategy interact in influencing the extent of structural change in production. To that effect, the variable capturing the interaction between each of the "AfT" variables (either total AfT flows or its components) and "TCI" is included in model (1). Finally, Table 5 reports the estimates of model (1) specification that allows checking the robustness of the findings in Table 4, including by replacing the dependent variable "SCINAV" with "SCIMLI". 
Table 2 Effect of AfT flows and development strategy on structural change in production

\begin{tabular}{|c|c|c|c|c|}
\hline Variables & $\begin{array}{l}\log (\text { SCINAV) } \\
\text { (1) }\end{array}$ & $\begin{array}{l}\log (\mathrm{SCINAV}) \\
(2)\end{array}$ & $\begin{array}{l}\log (\mathrm{SCINAV}) \\
\text { (3) }\end{array}$ & $\begin{array}{l}\log (\mathrm{SCINAV}) \\
\text { (4) }\end{array}$ \\
\hline $\log (\mathrm{SCINAV})_{t-1}$ & $0.164(0.0269)^{* * *}$ & $0.295(0.0267)^{* * *}$ & $0.179(0.0132)^{* * *}$ & $0.228(0.0159)^{* * *}$ \\
\hline $\mathrm{TCl}$ & $0.0159(0.00454)^{* * *}$ & & $0.0159(0.00307)^{* * *}$ & $0.0488(0.0196)^{* *}$ \\
\hline $\log ($ AfTTOTCST) & & $0.0343(0.0378)$ & $0.0743(0.0176)^{* * *}$ & $0.0620(0.0132)^{* * *}$ \\
\hline$[\mathrm{TCl}] \times[\log (\mathrm{GDPC})]$ & & & & $-0.00698(0.00289)^{* *}$ \\
\hline $\mathrm{TP}$ & $0.000529(0.00396)$ & $-0.00243(0.00473)$ & $0.000189(0.00266)$ & $-0.00165(0.00287)$ \\
\hline EDU & $\begin{array}{l}-0.0110 \\
(0.00162)^{* * *}\end{array}$ & $-0.00284(0.00153)^{*}$ & $\begin{array}{l}-0.0110 \\
(0.00127)^{* * * *}\end{array}$ & $\begin{array}{l}-0.00855 \\
(0.00113)^{* * *}\end{array}$ \\
\hline FINDEV & $0.00818(0.00163)^{* * *}$ & $-0.00237(0.00173)$ & $0.00353(0.00105)^{* * *}$ & $0.000857(0.000876)$ \\
\hline $\log (G D P C)$ & $0.00750(0.0431)$ & $0.131(0.0611)^{* *}$ & $0.116(0.0328)^{* * *}$ & $0.144(0.0277)^{* * *}$ \\
\hline $\log (P O P)$ & $-0.180(0.0298)^{* * *}$ & $-0.107(0.0477)^{* *}$ & $-0.262(0.0215)^{* * *}$ & $-0.229(0.0180)^{* * *}$ \\
\hline SHARABLE & $-0.00135(0.00364)$ & $0.0125(0.00447)^{* * *}$ & $0.00540(0.00237)^{* *}$ & $0.00539(0.00178)^{* * *}$ \\
\hline INST & $-0.139(0.0307)^{* * *}$ & $-0.0353(0.0486)$ & $-0.123(0.0234)^{* * *}$ & $-0.145(0.0259)^{* * *}$ \\
\hline Constant & $-0.698(0.773)$ & $-2.586(0.942)^{* * *}$ & $-1.299(0.441)^{* * *}$ & $-1.067(0.300)^{* * *}$ \\
\hline $\begin{array}{l}\text { Observations-coun- } \\
\text { tries }\end{array}$ & $356-81$ & $435-81$ & $334-81$ & $334-81$ \\
\hline $\begin{array}{l}\text { Number of Instru- } \\
\text { ments }\end{array}$ & 64 & 64 & 74 & 75 \\
\hline AR1 ( $p$ value) & 0.0000 & 0.0000 & 0.0000 & 0.0000 \\
\hline AR2 ( $p$ value) & 0.7562 & 0.2204 & 0.3374 & 0.2883 \\
\hline AR3 ( $p$ value) & 0.2605 & 0.8121 & 0.4544 & 0.3923 \\
\hline Sargan ( $p$ value) & 0.6131 & 0.4734 & 0.3198 & 0.2523 \\
\hline
\end{tabular}

Robust standard errors are in parenthesis. In the regressions, the variables "AfTTOTCST, TCI, TP, EDU, and FINDEV" have been considered as endogenous. The other variables have been considered as exogenous

Estimator: Two-step system GMM

${ }^{*} p$ value $<0.1 ; * * p$ value $<0.05$; *** $p$ value $<0.01$

\section{Results and discussion}

Across the four columns of Table 1, results indicate that the total AfT flows do not affect the extent of structural change in production. At the same time, results in columns [1], [2] and [4] (based, respectively, on the POLS-DK, FE-DK, and FGLS) show a negative and significant effect of TCI at the 5\% level, thereby indicating that the CAF strategy is associated with a greater extent of structural change in production. Meanwhile, results in column [3] (based on the random effects estimator) indicate no significant effect of $\mathrm{TCI}$ on the extent of structural change in production. With regard to control variables, we observe that trade policy liberalization does not affect the extent of structural change in production. The education level tends to be negatively and significantly related to the extent of structural change in production, thereby suggesting that higher education level likely induces a higher concentration in some production sectors at the expense of other sectors. Real per capita income (measure of the development level) exhibits alternatively negative and positive significant coefficients, respectively, in columns [2] and [4], but no significant coefficient at the $10 \%$ level in columns [1] and [3]. While financial development exerts no significant effect on the extent of structural change in production, the share of arable land in total land area tends to be positively associated with a higher extent of structural change in production. Likewise, the population size and the institutional and governance quality tend to induce a lower extent of structural change in production, that is, they tend to lead to a concentration of production in some sectors 
Table 3 Effect of the components of AfT flows and development strategy on structural change in production

\begin{tabular}{|c|c|c|c|}
\hline Variables & $\begin{array}{l}\log (\text { SCINAV) } \\
\text { (1) }\end{array}$ & $\begin{array}{l}\log (\text { SCINAV) } \\
\text { (2) }\end{array}$ & $\begin{array}{l}\log (\mathrm{SCINAV}) \\
\text { (3) }\end{array}$ \\
\hline $\log (\mathrm{SCINAV})_{t-1}$ & $0.197(0.0168)^{* * *}$ & $0.174(0.0139)^{* * *}$ & $0.222(0.0195)^{* * *}$ \\
\hline $\mathrm{TCl}$ & $0.0127(0.00324)^{* * *}$ & $0.0137(0.00358)^{* * *}$ & $0.00500(0.00201)^{* *}$ \\
\hline $\log ($ AfTINFRACST) & $0.0568(0.0136)^{* * *}$ & & \\
\hline $\log ($ AfTPRODCST) & & $-0.0503(0.0165)^{* * *}$ & \\
\hline $\log ($ AfTPOLCST) & & & $-0.0349(0.0165)^{* *}$ \\
\hline $\mathrm{TP}$ & $-0.000278(0.00272)$ & $0.00101(0.00213)$ & $0.00100(0.00216)$ \\
\hline EDU & $-0.00952(0.00106)^{* * *}$ & $-0.0104(0.00122)^{* * *}$ & $-0.00772(0.00101)^{* * *}$ \\
\hline FINDEV & $0.00194(0.001000)^{*}$ & $0.00648(0.000964)^{* * *}$ & $0.00277(0.000732)^{* * *}$ \\
\hline $\log (G D P C)$ & $0.128(0.0264)^{* * *}$ & $-0.0160(0.0349)$ & $-0.0109(0.0314)$ \\
\hline $\log (P O P)$ & $-0.219(0.0188)^{* * *}$ & $-0.167(0.0255)^{* * *}$ & $-0.117(0.0178)^{* * *}$ \\
\hline SHARABLE & $0.00994(0.00192)^{* * *}$ & $0.00654(0.00254)^{* *}$ & $0.000596(0.00294)$ \\
\hline INST & $-0.119(0.0285)^{* * *}$ & $-0.106(0.0195)^{* * *}$ & $-0.136(0.0238)^{* * *}$ \\
\hline Constant & $-1.297(0.325)^{* * *}$ & $0.158(0.546)$ & $-0.801(0.449)^{*}$ \\
\hline Observations-countries & $334-81$ & $334-81$ & $325-78$ \\
\hline Number of instruments & 74 & 74 & 74 \\
\hline AR1 ( $p$ value) & 0.0000 & 0.0000 & 0.0000 \\
\hline AR2 ( $p$ value) & 0.2804 & 0.4139 & 0.2646 \\
\hline AR3 ( $p$ value) & 0.3786 & 0.4461 & 0.4371 \\
\hline Sargan ( $p$ value) & 0.2244 & 0.1855 & 0.3818 \\
\hline
\end{tabular}

Estimator: Two-step system GMM

Robust standard errors are in parenthesis. In the regressions, the variables AfTINFRACST, AfTPRODCST, AfTPOLCST, TCI, TP, EDU, and FINDEV have been considered as endogenous. The other variables have been considered as exogenous. Time dummies have been included in the regressions

${ }^{*} p$ value $<0.1 ; * *$ value $<0.05$; *** $p$ value $<0.01$

of the economy. As noted above, these results might be biased due to several endogeneity concerns, and plausible results would be obtained here from regressions based on the two-step system GMM approach (see Tables 2, 3, 4, 5). However, before interpreting these results as well as those reported in the other tables, it is important to say few words on the results of the diagnostic tests that allow examining the validity of the twostep system GMM estimator used to perform the empirical analysis. The outcomes of these diagnostic tests are provided at the bottom of all columns of Tables [2] to [5], and are clearly satisfactory, as they confirm the appropriateness of this estimator. Specifically, we note across all these columns that the $p$ values related to $\mathrm{AR}(1)$ test are 0 , while the $\mathrm{p}$-values of the $\mathrm{AR}(2)$ and $\mathrm{AR}(3)$ tests are higher than $10 \%$. Moreover, the $\mathrm{p}$-value of the Sargan test is always higher than $10 \%$, and the number of instruments used in the regressions is always lower than the number of countries.

Results in column [1] (based on the estimation of model (1) without the "AfTTOTCST" variable) indicate that the development strategy based on the CAD approach induces a higher extent of structural change in production (the coefficient of the TCI variable is positive and statistically significant at the $1 \%$ ). The estimates reported in column [2] (based on the estimation of model (1) without the "TCI" variable) suggest that AfT flows do not influence structural change in production. In column [3] where model (1) is estimated as it is (i.e., with both TCI and AfT variables, here total AfT variable), we obtain a positive and significant effect of both AfT and TCI on the extent of structural 


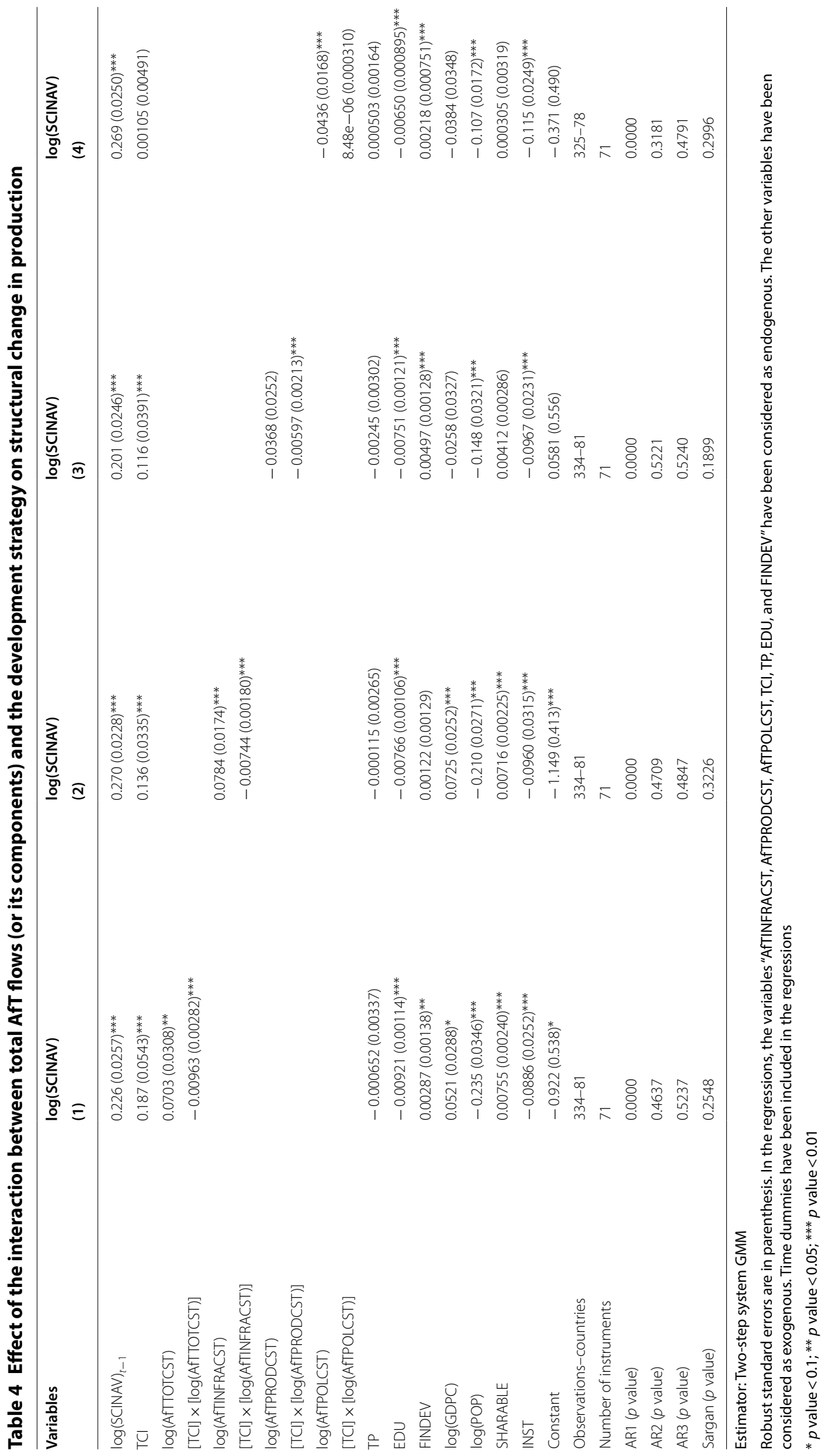


Table 5 Effect of the total AfT flows and development strategy on structural change in production ("SCMLI")

\begin{tabular}{|c|c|c|}
\hline Variables & $\begin{array}{l}\log (S C I M L I) \\
\text { (1) }\end{array}$ & $\begin{array}{l}\log (S C I M L I) \\
(2)\end{array}$ \\
\hline $\log (S C I M L I)_{t-1}$ & $0.162(0.0179)^{* * *}$ & $0.212(0.0308)^{* * *}$ \\
\hline $\mathrm{TCl}$ & $0.0124(0.00262)^{* * *}$ & $0.147(0.0485)^{* * *}$ \\
\hline $\log ($ AfTTOTCST) & $0.0615(0.0221)^{* * *}$ & $0.0545(0.0231)^{* *}$ \\
\hline$[\mathrm{TCl}] \times[\log ($ AfTTOTCST) $]$ & & $-0.00753(0.00253)^{* * *}$ \\
\hline TP & $0.00353(0.00214)^{*}$ & $0.00127(0.00296)$ \\
\hline EDU & $-0.00890(0.000960)^{* * *}$ & $-0.00706(0.000992)^{* * *}$ \\
\hline FINDEV & $0.00250(0.000940)^{* * *}$ & $0.00106(0.00117)$ \\
\hline $\log (G D P C)$ & $0.0605(0.0301)^{* *}$ & $0.0235(0.0287)$ \\
\hline $\log (P O P)$ & $-0.305(0.0157)^{* * *}$ & $-0.254(0.0289)^{* * *}$ \\
\hline SHARABLE & $0.00931(0.00257)^{* * *}$ & $0.00560(0.00315)^{*}$ \\
\hline INST & $-0.114(0.0258)^{* * *}$ & $-0.0582(0.0298)^{*}$ \\
\hline Constant & $-0.0137(0.426)$ & $-0.338(0.419)$ \\
\hline Observations-countries & $327-80$ & $327-80$ \\
\hline Number of instruments & 74 & 71 \\
\hline AR1 ( $p$ value) & 0.0000 & 0.0000 \\
\hline AR2 ( $p$ value) & 0.6695 & 0.8697 \\
\hline AR3 ( $p$ value) & 0.5287 & 0.5617 \\
\hline Sargan ( $p$ value) & 0.3275 & 0.4172 \\
\hline
\end{tabular}

Estimator: Two-step system GMM

Robust standard errors are in parenthesis. In the regressions, the variables AfTTOTCST, TCI, TP, EDU, and FINDEV have been considered as endogenous. The other variables have been considered as exogenous. Time dummies have been included in the regressions

${ }^{*} p$ value $<0.1 ;{ }^{* *} p$ value $<0.05 ;{ }^{* *} p$ value $<0.01$

change in production. These results suggest that while AfT flows induce a higher extent of structural change in production, surprisingly the CAD development strategy (and not the CAF strategy) results in a greater extent of structural change in production. This outcome might reflect the fact that the effect of the CAF development strategy on the extent of structural change in production depends on other variables, including AfT flows (this is what we will check in Table 4). This peculiar result leads us to check whether there are differentiated effects of TCI on the extent of structural change in production across countries, depending on the latter's development levels. In that respect, we present in column [4] of Table 2 the outcome of the estimation of a specification of model (1), which includes the interaction between TCI and the real per capita income, which acts as an indicator of countries' development levels. While results confirm the positive and significant effect of total real AfT and TCI on the extent of structural change in production, they also clearly indicate a negative and significant effect (at the 5\% level) of the interaction term. These suggest that as countries develop, the extent of structural change in production is positively driven by the CAF development strategy. In particular, there is a threshold of the real per capita income above which the CAF development strategy exerts a positive effect on the extent of structural change in production, as below this threshold, it is rather the CAD development strategy that generates greater structural change in production. This average threshold is given by US\$ 1087.25 [= exponential (0.0488/0.00698)]. Thus, the CAD development strategy induces a higher extent of 
structural change in production mainly in low-income countries. Focusing on results reported in column [3], we note about the outcomes concerning the control variables that trade policy liberalization exerts no significant effect on the extent of structural change in production, while higher financial development, higher development level, and higher share of arable land in total land area are positively and significantly associated with the extent of structural change in production. The education level, the population size and the quality of institutions and governance are negatively associated with the extent of structural change in production (the coefficients of these variables are negative and statistically significant at least at the $1 \%$ level). These suggest that these factors tend to lead countries to concentrate their production on some sectors in the economy. Note that estimates associated with controls in column [4] of Table 2 are quite similar to those in column [3] of the same table.

Table 3 reports results of the estimation of variants of model (1) where the variable "AfT" is not the total AfT flows, but rather the components of the latter. We obtain that AfT interventions for economic infrastructure generate a higher extent of structural change in production (see column [1]), whereas AfT for productive capacity building and AfT associated with trade policies and regulations induce a lower extent of structural change in production. These results indicate that trade costs reduction through the development of economic infrastructure promote structural change in production, while the build-up of productive capacity and Aid for Trade policies and regulations tend to lead countries to expand the production in some sectors at the expense of others, and hence reduces the extent of structural change across all economic sectors considered in the study. We also obtain here, in confirmation of results in Table 2, that higher values of TCI are associated with a positive effect on the extent of structural change, thereby indicating that it is the CAD development strategy that results in a greater extent of structural change in production, although this peculiar result could reflect differentiated effects across countries, depending on their development levels. The estimates related to control variables in the three columns of Table 3 are broadly consistent with those in column [3] of Table 2.

We now consider estimates in Table 4, which allow to examine the extent to which AfT flows (total AfT as well as its components) and the CAF/CAD strategy interact in influencing the extent of structural change in production in AfT recipient-countries. Results in column [1] suggest a positive and significant effect (at the 5\% level) of the total AfT flows on the extent of structural change in production. At the same time, the interaction term associated with the interaction variable between the total AfT flows and TCI is negative and statistically significant at the $1 \%$ level, thereby suggesting that AfT (total AfT flows) are complementary with the CAF strategy in inducing a greater extent of structural change in production. Thus, in the context of higher AfT flows, countries that adopt a CAD strategy experience a lower extent of structural change in production, while countries with a CAF strategy enjoy a greater extent of structural change in production. In other words, if governments want to reap the benefits of AfT flows in terms of structural change in production, they will be better off adopting the CAF development strategy. This finding is line with studies such as Ghimire et al. (2013) who have shown that AfT flows allocated to a given sector in the economy is positively associated with the exports of this sector. The same patterns of results are obtained in columns [2] and [3] concerning the interaction between TCI and, respectively, AfT related to economic 
infrastructure and AfT for productive capacity building. Furthermore, results in columns [1] to [2] indicate that there is a threshold of AfT amounts above which the total effect of AfT (total AfT and AfT for economic infrastructure) on the extent of structural change in production changes sign. These thresholds of total AfT and AfT for economic infrastructure are given, respectively, by $\$$ US 0.27 billion [= exponential $(0.187 / 0.00963)$ ] and \$US 86.8 million [=exponential $(0.136 / 0.00744)]$. Thus, countries that receive total AfT amounts lower than \$US 0.27 billion (or total amounts of AfT for economic infrastructure lower than \$US 86.8 million) tend to experience a positive effect of the CAD development strategy on the extent of structural change in production, and countries that receive AfT amounts higher than \$US 0.27 billion (or total amount of AfT for economic infrastructure higher than \$US 86.8 million) tend to experience a positive effect of the CAF development strategy on the extent of structural change in production. On the other hand, there are thresholds of TCI above which the total effects of, respectively, total AfT flows and AfT flows allocated to economic infrastructure on the extent of structural change in production change sign. These thresholds are, respectively, given by 7.3 $(=0.0703 / 0.00963)$ and $10.54(=0.0784 / 0.00744)$, respectively, for results in columns [1] and [2]. Hence, countries whose TCI values are lower than the threshold 7.3 experience a positive effect of total AfT flows on the extent of structural change in production (and for these countries, the lower the value of the TCI, i.e., when the development strategy is increasingly a CAF strategy, the higher the extent of structural change in production). In contrast, countries with TCI values higher than this threshold, experience a reducing effect of total AfT flows on the extent of structural change. The same reasoning applies to AfT related to economic infrastructure, although the threshold amounts here to 10.54 .

As for Aid for productive capacity building (see column [3]), we obtain that the interaction term is negative and significant at the $1 \%$ level, whereas the coefficient of the total AfT variable is not statistically significant at the $10 \%$ level. Taking together, these two results indicate that on average, AfT for productive capacity building consistently induces a greater extent of structural change in production when countries adopt a CAF strategy: the lower the values of TCI (i.e., the strong is the CAF strategy), the higher is the extent of structural change in production. With regard to results displayed in column [4], we obtain on the one hand that the coefficient of the variable capturing AfT related to trade policies and regulations is negative and statistically significant, whereas the interaction term is positive, but not statistically significant at the conventional levels. On the basis of these two results, we conclude that, on average, there is no combined effect of AfT associated with trade policies and regulations and the development strategy (CAF or CAD) on the extent of structural change in production. Results concerning control variables in columns [1] to [4] align with those in column [3] of Table 2.

The results concerning the effect of the interaction between the total AfT flows and TCI on the extent of structural change in production reflects an average effect and may therefore hide differentiated impacts of total AfT flows (including in terms of magnitude, sign, and statistical significance) on the extent of structural change in production, for varying levels of TCI. For this reason, we display in Fig. 5, at the 95 per cent confidence intervals, the development of the marginal impact of "TCI" on "SCINAV" for varying amounts of total AfT flows that accrue to recipient-countries. The marginal impacts that are statistically significant at the 95 per cent confidence intervals are those encompassing only the upper and lower bounds of 


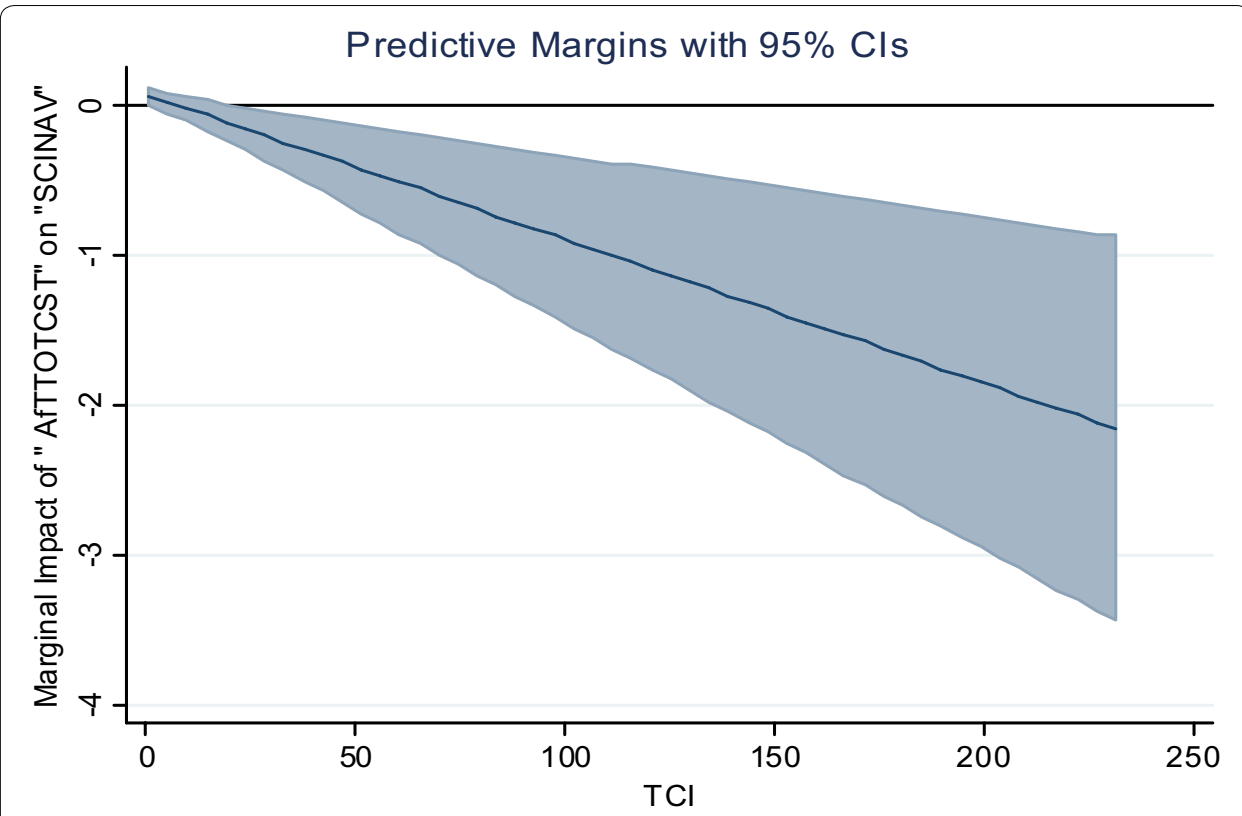

Fig. 5 Marginal impact of "AfTTOTCST" on "SCINAV", for varying degrees of TCI (Source: Author)

the confidence interval that are either above or below the zero line. The figure shows that the marginal impact of "TCI" on "SCINAV" decreases as countries receive higher amounts of total AfT flows. However, this marginal impact is not always statistically significant. Specifically, it is positive and statistically significant for amounts of AfT flows lower than (or equal to) \$US 0.215 billion [=exponential (19.18639)], and negative and statistically significant for AfT values strictly higher than \$US billion 0.51 [=exponential (20.0579)]. These results, therefore, indicate that countries enjoy a positive effect of the CAF development strategy on the extent of structural change in production only when they receive very high amounts of AfT, in particular when AfT amounts exceed \$US 0.51 billion. Hence, countries that receive AfT amounts lower than \$US 0.215 billion experience a positive effect of TCI on SCINAV, i.e., in these countries, the adoption of a CAD development strategy induces a greater extent of structural change in production. In contrast, countries that enjoy AfT flows higher than \$US 0.51 billion experience a positive effect of the CAF development strategy (or a negative effect of the CAD development strategy) on the extent of structural change. For these countries, the higher the AfT amounts, the higher is the positive effect of the CAF development strategy on the extent of structural change in production. Overall, the figure shows that countries that experience higher amounts of AfT flows tend to progressively reduce the reliance on the $\mathrm{CAD}$ development strategy (and increasingly adopt the CAF development strategy) so as to promote structural change in production.

Symmetrically, we present in Fig. 5, at the 95 per cent confidence intervals, the development of the marginal impact of "AfTTOTCST" on "SCINAV" for various countries' levels of TCI. The figure shows that the marginal impact of "AfTTOTCST" on "SCINAV" decreases as countries experience higher TCI values, and is almost always positive and statistically significant. Specifically, it is positive and statistically significant for TCI values lower than (or equal to) 0.48 , and statistically nil for TCI values comprised between 0.48 and 23.6. For TCI values higher than (or equal to) 23.6, the marginal effect of the total AfT 
on the extent of structural change in production is negative and statistically significant. Hence, total AfT flows reduce the extent of structural change in production in recipientcountries that experience TCI values higher than 23.6. In addition, for these countries, the higher the values of the TCI, the higher is the magnitude of the negative effect of total AfT on the extent of structural change in production. As a result, countries that implement CAF strategies experience a positive effect of AfT flows on the extent of structural change in production: AfT interventions are complementary with the CAF development strategy in inducing a higher extent of structural change in production. For countries with $\mathrm{TCI}$ values lower than 0.48 , AfT flows are substitutable with countries' CAF development strategy. Finally, countries with values of TCI ranging from 0.48 to 23.6 experience no significant effect of AfT flows on the extent of structural change in production.

As noted in the previous section, the robustness of findings in Table 4 is checked by replacing SCINAV with SCIMLI in model (1). The results of the estimation of this model specification without/and with the interaction between "TCI" and the total AfT variable are reported, respectively, in columns [1] and [2] of Table 5. These results are largely consistent with those in Table 4, notably in terms of direction of the effects of AfT, TCI and the interaction variable on structural change in production. Specifically, we obtain in columns [1] and [2] that higher total AfT flows induce a greater extent of structural change in production, while the interaction term exhibits a negative sign (as in Table 4), which indicates that total AfT flows promotes structural change in production when countries adopt the CAF development strategy. The threshold of TCI below which the total effect of total AfT flows on the extent of structural change in production is positive is given by 7.24 (which is close to the threshold of 7.3 obtained in Table 4). Estimates of controls are to a large extent consistent with those in Table 4.

\section{Conclusion}

This paper examines how AfT flows interact with countries' development strategy based on the comparative advantage (CAD or CAF) in influencing the extent of structural change in production. The analysis is conducted using an unbalanced panel dataset, which contains 81 countries over the period 1996-2016. Based on the two-step system GMM approach, the estimations' results have shown that total AfT flows are complementary with the CAF development strategy in promoting structural change in production. These findings show that as the international community, including donorcountries and international financial and regional institutions are working with national policymakers of developing countries to promote economic diversification and structural change (including in production), the provision of higher AfT flows to these governments should be accompanied by the adoption of the CAF development strategy so as to achieve the intended objective of promoting structural change in production.

\footnotetext{
Abbreviations

AfT: Aid for Trade; CAF: Comparative Advantage Following strategy; CAD: Comparative Advantage Defying strategy; GMM: Generalized Methods of Moments; IMF: International Monetary Fund; NSE: New Structural Economics; UNIDO: United Nations Industrial Development Organization; UNCTAD: United Nations Conference on Trade and Development; WTO: World Trade Organization.
} 


\section{Acknowledgements}

This paper represents the personal opinions of individual staff members and is not meant to represent the position or opinions of the WTO or its Members. The authors would like to express their sincere gratitude to the anonymous Reviewers for their useful comments on an earlier version this article. Any errors or omissions are the fault of the author.

\section{Authors' contributions}

The author drafts alone all sections of the paper. The author read and approved the final manuscript.

Funding

This work has not received any financial support.

Availability of data and materials

Data and material would be made available upon request.

\section{Competing interests}

I have not provided any comments on articles published in the Journal of Economic Structures. Therefore, there is no financial competing and non-financial competing interests relating to any comments provided on the Journal of Economic Structures. Additionally, I hereby confirm that there are no potential conflicts of interest relating to this paper apart from the Disclaimer included in the "Acknowledgements" section. The paper does not require any "Informed Consent".

\section{Appendix 1}

See Table 6.

\section{Table 6 Definitions and sources of variables}

\begin{tabular}{|c|c|c|}
\hline Variable & Definition & Source \\
\hline $\mathrm{TCl}$ & $\begin{array}{l}\text { This is the Technology Choice Index, } \\
\text { which is a proxy for the development } \\
\text { strategy (i.e., CAF or CAD) adopted by a } \\
\text { given country }\end{array}$ & $\begin{array}{l}\text { Author's calculation based on the formula } \\
\text { described in Sect. 3. Data on the added } \\
\text { value of manufacturing industries } \\
\left(\text { AVM }_{i t} \text { ) as well as data on the labour }\right. \\
\left.\text { in the manufacturing industry (LM }{ }_{i t}\right) \\
\text { are collected from the database of the } \\
\text { United Nations Industrial Development } \\
\text { Organization (https://wWw.unido.org/ } \\
\text { researchers/statistical-databases). Data } \\
\text { on total added value (GDP) and total } \\
\text { labour force (Lit) is obtained from the } \\
\text { World Development Indicators (WDI) of } \\
\text { the World Bank }\end{array}$ \\
\hline $\begin{array}{l}\text { AfTTOTCST, AfTINFRACST, } \\
\text { AfTPRODCST, and } \\
\text { AfTPOLCST }\end{array}$ & $\begin{array}{l}\text { "AfTTOTCST" is the total AfT gross } \\
\text { disbursements (in constant } 2016 \text { US } \\
\text { dollars) } \\
\text { "AfTINFRACST" is the gross disbursements } \\
\text { AfT allocated to Economic Infrastruc- } \\
\text { ture (in constant } 2016 \text { US dollars) } \\
\text { "AfTIPRODCST" is the gross disburse- } \\
\text { ments AfT allocated to Productive } \\
\text { Capacity Building (in constant } 2016 \text { US } \\
\text { dollars) } \\
\text { "AfTPOLCST" is the gross disbursements } \\
\text { AfT related to Trade Policies and Regu- } \\
\text { lations (in constant } 2016 \text { US dollars) }\end{array}$ & $\begin{array}{l}\text { Author's calculation based on sectoral } \\
\text { development aid data collected from } \\
\text { the OECD/DAC-CRS (Organization for } \\
\text { Economic Cooperation and Develop- } \\
\text { ment/Donor Assistance Committee)- } \\
\text { Credit Reporting System (CRS). AfT data } \\
\text { is computed on the basis the following } \\
\text { three categories (the CRS Codes are in } \\
\text { brackets): } \\
\text { Economic Infrastructure: transport and } \\
\text { storage (210), communications (220), } \\
\text { and energy } \\
\text { generation and supply (230); Building } \\
\text { Productive Capacity: banking and finan- } \\
\text { cial services (240), business and other } \\
\text { services (250), agriculture (311), forestry } \\
\text { (312), fishing (313), industry (321), } \\
\text { mineral resources and mining (322), } \\
\text { and tourism (332); and Trade policy and } \\
\text { regulations: trade policy and regulations } \\
\text { and trade-related adjustment (331) }\end{array}$ \\
\hline GDPC & GDP per capita (constant 2010 US\$) & WDI 2018 \\
\hline
\end{tabular}


Table 6 (continued)

\begin{tabular}{|c|c|c|}
\hline Variable & Definition & Source \\
\hline $\mathrm{TP}$ & $\begin{array}{l}\text { This variable represents the measure of } \\
\text { trade policy. The trade policy index is } \\
\text { indeed the "Freedom to international } \\
\text { trade" score used as a major compo- } \\
\text { nent of the Economic Freedom Index. It } \\
\text { is composite measure of the absence of } \\
\text { tariff and non-tariff barriers that affect } \\
\text { imports and exports of goods and } \\
\text { services. Its computation is based on } \\
\text { two components: trade-weighted aver- } \\
\text { age tariff rage and non-tariff barriers } \\
\text { (NTBs), the extent of latter having been } \\
\text { determined on the basis of quantitative } \\
\text { and qualitative available information. } \\
\text { NTBs include quantity restrictions, } \\
\text { price restrictions, regulatory restric- } \\
\text { tions, investment restrictions, customs } \\
\text { restrictions, and direct government } \\
\text { interventions. This score is graded on a } \\
\text { scale of } 0 \text { to 100, with a rise indicating } \\
\text { lower trade barriers, i.e., higher trade } \\
\text { liberalization, while a decrease reflects } \\
\text { rising trade protectionism }\end{array}$ & $\begin{array}{l}\text { Heritage Foundation (see Miller et al. } \\
\text { 2017) }\end{array}$ \\
\hline EDU & $\begin{array}{l}\text { Average of the gross rate of primary, } \\
\text { secondary and tertiary school enroll- } \\
\text { ment (\%) }\end{array}$ & $\begin{array}{l}\text { Author's calculation based on data from } \\
\text { the WDI }\end{array}$ \\
\hline FINDEV & $\begin{array}{l}\text { This is the measure of the depth of finan- } \\
\text { cial development. It is measured by the } \\
\text { domestic credit to private sector (\% of } \\
\text { GDP), where missing values have been } \\
\text { replacing with the domestic credit to } \\
\text { private sector by banks (\% of GDP) }\end{array}$ & WDI \\
\hline SHARABLE & $\begin{array}{l}\text { This is the share (\%) of arable land in total } \\
\text { land area }\end{array}$ & WDI \\
\hline POP & Total population & WDI \\
\hline INST & $\begin{array}{l}\text { This variable represents the quality } \\
\text { of institutions and governance in a } \\
\text { given AfT recipient-country. It has } \\
\text { been calculated by extracting the first } \\
\text { principal component (based on factor } \\
\text { analysis) of the following six indica- } \\
\text { tors of governance. These indicators } \\
\text { include a measure of political stability } \\
\text { and absence of violence/terrorism; a } \\
\text { measure of regulatory quality policy; an } \\
\text { indicator of Rule of Law; a measure of } \\
\text { Government Effectiveness; an indicator } \\
\text { of voice and accountability; and finally, } \\
\text { a measure of corruption. It is worth } \\
\text { noting that higher values of the index } \\
\text { "INST" are associated with better gov- } \\
\text { ernance and institutional quality, while } \\
\text { lower values reflect worse governance } \\
\text { and institutional quality }\end{array}$ & $\begin{array}{l}\text { Data on the components of "INST" has } \\
\text { been extracted from World Bank } \\
\text { Governance Indicators developed by } \\
\text { Kaufmann, Kraay and Mastruzzi (2010) } \\
\text { and updated in } 2018\end{array}$ \\
\hline
\end{tabular}

\section{Appendix 2}

See Table 7. 
Table 7 Descriptive statistics on variables

\begin{tabular}{llcccc}
\hline Variable & Observations & Mean & Standard deviation & Minimum & Maximum \\
\hline SCINAV & 567 & 0.019 & 0.013 & 0.003 & 0.119 \\
SCIMLI & 557 & 0.019 & 0.013 & 0.003 & 0.119 \\
AfTTOTCST & 537 & $2.65 e+08$ & $4.53 \mathrm{e}+08$ & $67,837.2$ & $3.65 \mathrm{e}+09$ \\
AfTINFRACST & 536 & $1.55 \mathrm{e}+08$ & $2.97 \mathrm{e}+08$ & $17,984.67$ & $3.04 \mathrm{e}+09$ \\
AfTPRODCST & 537 & $1.08 \mathrm{e}+08$ & $1.88 \mathrm{e}+08$ & $43,864.5$ & $1.96 \mathrm{e}+09$ \\
AfTPOLCST & 480 & $4,613,200$ & $1.46 \mathrm{e}+07$ & 201.3659 & $2.64 \mathrm{e}+08$ \\
TCI & 431 & 7.227 & 19.574 & 0.475 & 231.683 \\
GDPC & 566 & 4761.654 & 5175.947 & 194.926 & $24,892.790$ \\
TP & 549 & 67.068 & 12.865 & 13.467 & 89.200 \\
EDU & 557 & 69.965 & 20.124 & 4.199 & 111.962 \\
FINDEV & 555 & 37.184 & 31.763 & 0.186 & 155.407 \\
POP & 566 & $5.92 \mathrm{e}+07$ & $1.93 \mathrm{e}+08$ & $264,269.3$ & $1.37 \mathrm{e}+09$ \\
SHARABLE & 564 & 14.654 & 13.716 & 0.088 & 64.534 \\
\hline
\end{tabular}

\section{Appendix 3}

See Table 8.

Table 8 List of countries contained in the full sample

\begin{tabular}{lll}
\hline Entire sample & & \\
\hline Albania & Georgia & Myanmar \\
Algeria & Ghana & Nepal \\
Angola & Guatemala & Niger \\
Argentina & India & Oman \\
Armenia & Indonesia & Pakistan \\
Azerbaijan & Iran, Islamic Rep. & Panama \\
Bahrain & Jamaica & Papua New Guinea \\
Bangladesh & Jordan & Paraguay \\
Belarus & Kazakhstan & Peru \\
Bolivia & Kenya & Philippines \\
Botswana & Korea, Rep. & Saudi Arabia \\
Brazil & Kyrgyz Republic & Senegal \\
Burundi & Lao PDR & Slovenia \\
Cambodia & Lebanon & South Africa \\
Cameroon & Lesotho & Sri Lanka \\
Chile & Macedonia, FYR & Suriname \\
China & Madagascar & Tajikistan \\
Colombia & Malawi & Tanzania \\
Costa Rica & Malaysia & Thailand \\
Croatia & Maldives & Trinidad and Tobago \\
Ecuador & Mauritius & Tunisia \\
Egypt, Arab Rep. & Mexico & Turkey \\
Eritrea & Moldova & Uganda \\
Eswatini & Mongolia & Ukraine \\
Ethiopia & Montenegro & Uruguay \\
Fiji & Morocco & Vietnam \\
The Gambia & Mozambique & Yemen, Rep. \\
\hline & & \\
\hline
\end{tabular}


Received: 9 June 2019 Revised: 26 December 2019 Accepted: 6 January 2020

Published online: 21 January 2020

\section{References}

Acharyya R, Kar S (2014) International trade and economic development. Oxford University Press, USA Addison T, Tarp F (2015) Aid policy and the macroeconomic management of aid. World Dev 69:1-5

Addison T, Morrissey O, Tarp F (2017) The macroeconomics of aid: overview. J Dev Stud 53(7):987-997

Agénor P-R, Aizenman J (2010) Aid volatility and poverty traps. J Dev Econ 91(1):1-7

Agosin R, Alvarez R, Bravo-Ortega C (2012) Determinants of Export Diversification around the World: 1962-2000. World Econ 35(3):295-315

Ahlerup P (2019) Foreign aid and structural transformation: Micro-level evidence from Uganda. Working Papers in Economics 755, University of Gothenburg, Department of Economics

Anderson TW, Hsiao C (1982) Formulation and estimation of dynamic models using panel data. J Econ 18(1):47-82

Arellano M, Bond S (1991) Some tests of specification for panel data: Monte Carlo evidence and an application to employment equations. Rev Econ Stud 58:277-298

Arellano M, Bover O (1995) Another look at the instrumental variable estimation of error-components models. J Econ 68(1):29-51

Arellano C, Buliř A, Lane T, Lipschitz L (2009) The dynamic implications of foreign aid and its variability. J Dev Econ 88(1):87-102

Bacchetta M, Jansen M (2003) Adjusting to trade liberalization: the role of policy, institutions and WTO disciplines. World Trade Organization, Special Studies, Geneva, p 7

Baldwin RE, Braconier H, Forslid R (2005) Multinationals, endogenous growth, and technological spillovers: theory and evidence. Rev Int Econ 13(5):945-963

Barro RJ, Sala-i-Martin X (1997) Technological diffusion, convergence, and growth. J Econ Growth 2(1):2-26

Blundell R, Bond S (1998) Initial conditions and moment restrictions in dynamic panel data models. J Econ 87(1):115-143

Blundell R, Bond S, Windmeijer F (2001) Estimation in dynamic panel data models: improving on the performance of the standard GMM estimator. Nonstationary Panels, Panel Cointegration, and Dynamic Panels. Emerald Group Publishing Limited, p 53-91

Bruno RL, Douarin E, Korosteleva J, Radosevic S (2015) Technology choices and growth: testing new structural economics in transition economies. J Econ Policy Reform 18(2):131-152

Busse M, Hoekstra R, Königer J (2012) The impact of Aid for Trade facilitation on the costs of trading. Kyklos 65:143-163

Calì M, TeVelde D (2011) Does Aid for Trade really improve trade performance? World Dev 39(5):725-740

Chang HJ (1994) The political economy of industrial policy. St. Martin's Press, New York

Chauvet L, Ehrhart H (2018) Aid and growth: evidence from firm-level data. J Dev Econ 135:461-477

Chen B, Lin JY (2008) Development strategy, economic performance and inequality. China Center for Economic Research (CCER) Economic Papers, no 100871

Cirera X, Winters LA (2015) Aid for Trade and structural transformation in Sub-Saharan Africa. Commonwealth Trade Policy Discussion Papers 2015/01, Commonwealth Secretariat, London

Clemens M, Radelet S, Bhavnani R, Bazzi S (2012) Counting chickens when they hatch: the short-term effect of aid on growth. Econ J 122(561):590-617

Cortuk O, Singh N (2011) Structural change and growth in India. Econ Lett 110(3):178-181

Dabla-Norris E, Thomas AH, Garcia-Verdu R, Chen Y (2013) Benchmarking Structural Transformation Across the World. Working Paper No. 13/176. International Monetary Fund (IMF), Washington, D.C

Dietrich A (2012) Does growth cause structural change, or is it the other way round? A dynamic panel data analysis for seven OECD countries. Empir Econ 43:915-944

Driscoll JC, Kraay AC (1998) Consistent covariance matrix estimation with spatially dependent panel data. Rev Econ Stat 80(4):549-560

Duarte M, Restuccia D (2010) The role of the structural transformation in aggregate productivity. Quart J Econ 125(1):129-173

Faruq H (2011) How institutions affect export quality. Econ Syst 35:586-606

Fine B, Waeyenberge EV (2013) A paradigm shift that never was: Justin Lin's new structural economics. Compet Change 17(4):355-371

Fiorini M, Jansen M, Kummritz V, Xie W (2013) Trade and the extent of structural change. Working Paper ESTG2013, European Trade Study Group, Bern. See online at: https://www.etsg.org/ETSG2013/Papers/221.pdf

Ghimire S, Mukherjee D, Alvi E (2013) Sectoral aid for trade and sectoral exports: a seemingly unrelated regression analysis. Econ Bull 33(4):2744-2755

Ghimire S, Mukherjee D, Alvi E (2016) Aid-for-Trade and Export Performance of Developing Countries,". Appl Econ Int Dev Euro-Am Assoc Econ Dev 16(1):23-34

Gnangnon SK (2019) Aid for Trade and export diversification in recipient-countries. World Econ 42(2):396-418

Grossman GM, Helpman E (1991) Innovation and growth in the global economy. MIT Press, Cambridge, London Hansen G, Prescott E (2002) Malthus to Solow. Am Econ Rev 92:1205-1217

Herrendorf B, Rogerson R, Valentinyi A (2014) Growth and structural transformation. In: Aghion P, Durlauf S (eds) Handbook of economic growth, vol 2. North-Holland, Amsterdam, pp 855-941

Hirschman AO (1958) The strategy of economic development. Yale University Press, New Haven

Hühne P, Meyer B, Nunnenkamp P (2014a) Who benefits from Aid for Trade? Comparing the effects on recipient versus donor exports. J Dev Stud 50(9):1275-1288 
Hühne P, Meyer B, Nunnenkamp P (2014b). Aid for trade: Assessing the effects on recipient exports of manufactures and primary commodities to donors and non-donors. Kiel Working Papers, No 1953. Kiel Institute for the World Economy (IfW), Kiel, Germany

Iqbal N, Daly V (2014) Rent seeking opportunities and economic growth in transitional economies. Econ Model 37:16-22 Jha R, Afrin S (2017) Pattern and Determinants of Structural Transformation in Africa. In: Lopes C, Hamdok A, Elhiraika A (eds) Macroeconomic policy framework for Africa's structural transformation. Palgrave Macmillan, Cham

Kaufmann D Kraay A, Mastruzzi M (2010) The worldwide governance indicators methodology and analytical issues. World Bank Policy Research No 5430 (WPS5430), Washington, D.C

Kuznets S (1972) Innovations and Adjustment in Economic Growth. Swed J Econ 74(4):431-451

Kuznets S (1973) Modern economic growth: findings and reflections. Am Econ Rev 63(3):247-258

Lahiri S (2006) Theory and practice of foreign aid: introduction. In: Lahiri S (ed) Theory and practice of foreign aid (Frontiers of Economics and Globalization), vol 1. Emerald Group Publishing Limited, Bingley, pp 25-28

Levine R (2005) Finance and growth: theory and evidence. In: Aghion P, Durlauf SN (eds) Handbook of economic growth. Elsevier, Amsterdam, pp 865-934

Lewis WA (1954) Economic development with unlimited supplies of labour. Manchester School, 22-139-191

Lilien DM (1982) Sectoral shifts ad cyclical unemployment. J Polit Econ 90:777-793

Lin JY (2004) Development strategies for inclusive growth in developing Asia. Asian Dev Rev 21(2):1-27

Lin J (2010) New structural economics. A framework for rethinking development. Policy Research Paper 5197, World Bank, Washington, DC

Lin JY (2011) New structural economics: a framework for rethinking development. World Bank Res Obs 26(2):193-221

Lin JY (2012) New structural economics. A framework for rethinking development and policy. Chap. 6, Washington, DC: The World Bank, p 287-347

Lin JY (2015) The Washington consensus revisited: a new structural economics perspective. J Econ Policy Reform 18(2):96-113

Lin JY, Liu MX (2004) Development strategy, transition and challenges of development in lagging regions. In: Bourguignon F, Plekovic B (eds) Annual World Bank conference on development economics 2004. The World Bank, Washington, DC, pp 197-223

Losch B, Fréguin-Gresh S, White ET (2012) Structural transformation and rural change revisited challenges for late developing countries in a globalizing world. World Bank Publication, World Bank, Washington, D.C.

Martínez -Zarzoso I, Nowak-Lehmann F, Rehwald K (2017) Is Aid for Trade effective? A panel quantile regression approach. Rev Dev Econ 21(4):e175-e203

Martins PMG (2018) Structural change: pace, patterns and determinants. Rev Dev Econ 23(1):1-32

Matsuyama K (2005) Structural Change. In: Blume L, Durlauf S (eds) The new Palgrave dictionary of economics, 2nd edn. Macmillan, Houndmills

McMillan M, Rodrik D, Verduzco-Gallo I (2014) Globalization, structural change, and productivity growth, with an update on Africa. World Dev 63:11-32

Michaely M (1962) Concentration in international trade. North Holland, Amsterdam

Miller T, Kim AB, Roberts JM, Riley B, Whiting T (2017) 2017 Index of economic freedom, institute for economic freedom. The Heritage Foundation, Washington, DC. http://www.heritage.org/index/download

Nickell S (1981) Biases in dynamic models with fixed effects. Econometrica 49(6):1399-1416

Odedokun M (2003) Analysis of deviations and delays in aid disbursements. J Econ Dev 137(28):137-169

OECD/WTO (2017) Aid for Trade at a Glance 2017: promoting trade, inclusiveness and connectivity for sustainable development. In Chapter 11: Financing connectivity: aid for trade priorities, policies, and programmes. Contributed by the Organisation for Economic Cooperation and Development, WTO, Geneva/OECD Publishing, Paris. http://dx.doi. org/10.1787/aid_glance-2017-en

Page J (2012) Aid, structural change and the private sector in Africa. Working Paper No. 2012/21. UNU World Institute for Development Economics Research (UNU-WIDER), Helsinki, Finland

Prebisch R (1959) Commercial policy in underdeveloped countries. Am Econ Rev 49(2):251-273

Prebisch R (1960) The economic development of Latin America and its principal problems. Economic Commission for Latin America, New York

Productivity Commission (1998) Aspects of structural change in Australia. Research Report, AusInfo

Rodrik D (2011) Comments on New structural economics by Justin Yifu Lin, in World Bank Research Observer, 26, pp 227-229. Copy at http://j.mp/2nzl1QC

Roodman DM (2009) A note on the theme of too many instruments. Oxford Bull Econ Stat 71(1):135-158

Rosenstein-Rodan P (1943) Problems of industrialisation of Eastern and south-eastern Europe. Econ J 53:202-211

Selaya P, Sunesen ER (2012) Does foreign aid increase foreign direct investment? World Dev 40(11):2155-2176

Shorrocks A (2013) Decomposition procedures for distributional analysis: a unified framework based on the Shapley value. J Econ Inequal 11(1):99-126

Siddique AB (2015) Comparative advantage defying development strategy and cross-country poverty incidence. J Econ Dev 41(4):45-78

Stamer M (1998) Interrelation between subsidies, structural change and economic growth in Germany, a vector autoregressive analysis. Konjunkturpolitik 44(3):231-253

Stoikov V (1966) Some determinants of the level of frictional unemployment: a comparative study. Int Labour Rev 93:530-549

Syrquin M (2010) Kuznets and Pasinetti on the study of structural transformation: never the Twain shall meet?". Struct Change Econ Dyn 21(4):248-257

Thiele R, Nunnenkamp P, Dreher A (2006) Sectoral aid priorities: are donors really doing their best to achieve the millennium development goals?. Kiel Institute for World Economics Working Paper No. 1266

UNCTAD (2014) The Least Developed Countries Report 2014: growth with structural transformation: a post-2015 development agenda, United Nations Publication, Sales No. E.14.II.D.7. Geneva, Switzerland 
UNCTAD (2016) Virtual institute teaching material on structural transformation and industrial policy. UNCTAD, New York and Geneva. UNCTAD/GDS/2016/1

Williamson J (1990) What Washington means by policy reform. In: Williamson J (ed) Latin American adjustment: how much has happened?. Institute for International Economics, Washington, DC, pp 5-20

Williamson J (2004) A short history of the Washington Consensus. In: Paper presented at Foundation CIDOB conference held in Barcelona 'from the Washington Consensus towards a New Global Governance', Columbia University. http:// www.iie.com/publications/papers/williamson0904-2.pdf

\section{Publisher's Note}

Springer Nature remains neutral with regard to jurisdictional claims in published maps and institutional affiliations.

Submit your manuscript to a SpringerOpen ${ }^{\circ}$ journal and benefit from:

- Convenient online submission

- Rigorous peer review

- Open access: articles freely available online

- High visibility within the field

Retaining the copyright to your article

Submit your next manuscript at $>$ springeropen.com 